\title{
Venoms of Heteropteran Insects: A Treasure Trove of Diverse Pharmacological Toolkits
}

\author{
Andrew A. Walker ${ }^{1, *}$, Christiane Weirauch ${ }^{2}$, Bryan G. Fry ${ }^{3}$ and Glenn F. King ${ }^{1}$ \\ 1 Institute for Molecular Biosciences, The University of Queensland, St Lucia, QLD 4072, Australia; \\ glenn.king@imb.uq.edu.au \\ 2 Department of Entomology, University of California, Riverside, CA 92521, USA; \\ christiane.weirauch@ucr.edu \\ 3 School of Biological Sciences, The University of Queensland, St Lucia, QLD 4072, Australia; bgfry@uq.edu.au \\ * Correspondence: a.walker@uq.edu.au; Tel.: +61-7-3346-2011
}

Academic Editor: Jan Tytgat

Received: 21 December 2015; Accepted: 26 January 2016; Published: 12 February 2016

\begin{abstract}
The piercing-sucking mouthparts of the true bugs (Insecta: Hemiptera: Heteroptera) have allowed diversification from a plant-feeding ancestor into a wide range of trophic strategies that include predation and blood-feeding. Crucial to the success of each of these strategies is the injection of venom. Here we review the current state of knowledge with regard to heteropteran venoms. Predaceous species produce venoms that induce rapid paralysis and liquefaction. These venoms are powerfully insecticidal, and may cause paralysis or death when injected into vertebrates. Disulfide-rich peptides, bioactive phospholipids, small molecules such as $\mathrm{N}, \mathrm{N}$-dimethylaniline and 1,2,5-trithiepane, and toxic enzymes such as phospholipase $\mathrm{A}_{2}$, have been reported in predatory venoms. However, the detailed composition and molecular targets of predatory venoms are largely unknown. In contrast, recent research into blood-feeding heteropterans has revealed the structure and function of many protein and non-protein components that facilitate acquisition of blood meals. Blood-feeding venoms lack paralytic or liquefying activity but instead are cocktails of pharmacological modulators that disable the host haemostatic systems simultaneously at multiple points. The multiple ways venom is used by heteropterans suggests that further study will reveal heteropteran venom components with a wide range of bioactivities that may be recruited for use as bioinsecticides, human therapeutics, and pharmacological tools.
\end{abstract}

Keywords: venom; toxin; predation; haematophagy; paralysis; liquefaction; venomics; venom discovery; Heteroptera; true bugs

\section{Evolution of Venom Systems in Heteroptera}

\subsection{Introduction: Are Heteropterans Venomous Animals?}

The suborder Heteroptera or true bugs (Figure 1) are a morphologically and ecologically diverse group of insects within the order Hemiptera. Like the remaining groups of hemipterans (e.g., cicadas and aphids), the true bugs have piercing-and-sucking mouthparts. However, while other hemipterans are exclusively phytophagous, the true bugs have evolved to prey on arthropods and other animals and to become ectoparasites of vertebrates. Central to the evolution of these trophic shifts has been the adaptation of the piercing-and-sucking mouthparts—used by hemipterans to feed on plants-into a sophisticated venom apparatus. Since envenomation first evolved as a trophic strategy in an insect ancestral to present-day heteropterans, they have diversified into 42,000 species in 89 families and 
seven infraorders. Today, they occupy a wide range of ecosystems and represent one of the most successful radiations of hemimetabolous insects [1,2].

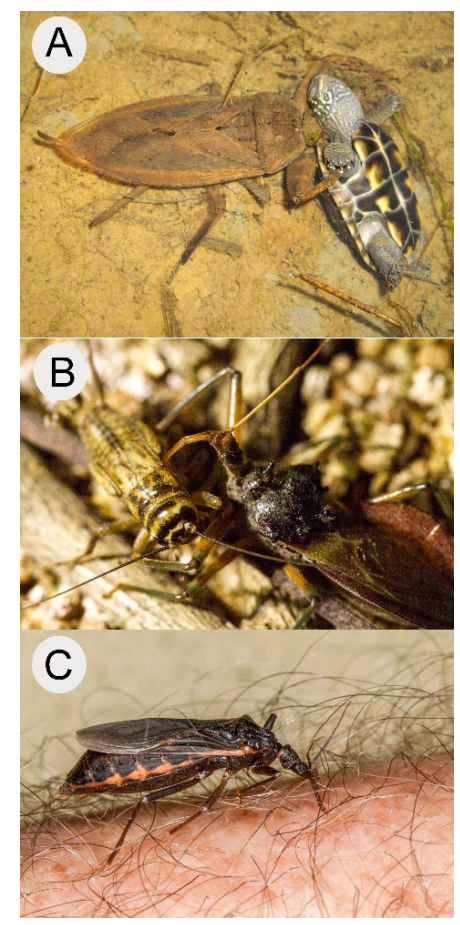

Figure 1. Venomous heteropterans. (A) An aquatic predaceous heteropteran, the giant water bug Kirkaldyia deyrolli, with turtle prey. Photo (C) Shin-ya Ohba; (B) A terrestrial predaceous heteropteran, the assassin bug Pristhesancus plagipennis, feeding on a cricket; (C) A blood-feeding heteropteran, Triatoma rubida, feeding on human blood. Photo ( Margy Green.

As a result of their widespread distribution, interactions between heteropterans and humans are frequent, diverse, and economically important. Kissing bugs (Reduviidae: Triatominae) bite vertebrates (including humans) to feed on their blood; in the process they spread trypanosomes responsible for Chagas disease-a condition that results in more than 7000 deaths per year and substantial diminution in quality of life for affected individuals [3] —and cause allergic responses including anaphylaxis [4]. Predaceous heteropterans such as assassin bugs (Reduviidae) and backswimmers (also known as water bees, Notonectidae) may bite humans, causing pain, tissue necrosis, numbness, respiratory disturbances, and in extreme cases, death [5-9]. While some plant-feeding heteropterans are agricultural pests that incur billions of dollars in management costs annually, others are valued biocontrol agents in agricultural ecosystems [1,10]. A central feature in each of these relationships between humans and the true bugs is envenomation. Thus, understanding the venom systems of heteropterans is a key feature in understanding both their evolutionary history and present-day management.

We regard all predaceous and blood-feeding heteropterans to be unambiguously venomous under the definition of Fry and colleagues [11]: "Venom is a secretion, produced in a specialised gland in one animal, and delivered to a target animal through the infliction of a wound ... a venom must further contain molecules that disrupt normal physiological or biochemical processes so as to facilitate feeding or defense by the producing animal". Unfortunately, there is a historical tradition among entomologists and venom researchers to confuse or discount the venomous nature of heteropterans. For example, Baptist [12] concludes his classic study of heteropteran labial glands by remarking that "The toxic nature of the saliva of the predaceous forms seems to be incidental to their being of the nature of digestive juices". The essence of this view, commonly echoed in more recent studies 
(e.g., [13]), is that true bugs inject digestive enzymes but not neurotoxins. In particular it is supposed they do not inject neurotoxins such as those found in the venoms of spiders, snakes, scorpions, cone snails, centipedes and cnidarians that bind to specific ion channels and receptors in the injected animal to quickly induce paralysis, pain or death [14-19]. The roots of this confusion lie in the unique feeding biology of heteropteran predators and a paucity of data on heteropteran venom biochemistry. Since hemipteran mouthparts only permit the uptake of liquid food, liquefaction of prey by extra-oral digestion (EOD) $[20,21]$ is of utmost importance to predaceous heteropterans to maximise nutrient intake (Section 1.2). The production of large quantities of concentrated enzymes to assist in EOD is undoubtedly a key function of the labial glands, which are also the source of venom. However, there is also clear and convincing evidence that heteropterans inject into their prey not only digestive enzymes but also neurotoxins and other pharmacological modulators.

The venom of predaceous species is not only used to digest prey, but for defense (by causing pain when injected into a potential predator) and to rapidly immobilise and kill prey. Edwards [6] noted more than half a century ago that venoms from assassin bugs such as Rhynocoris carmelita and Platymeris rhadamanthus are able to induce paralysis both potently (bugs being able to paralyse prey hundreds of times larger than themselves) and quickly (over a time scale of seconds). Some assassins such as Holotrichius innesi are even able to kill vertebrates by a single envenomation, which induces respiratory paralysis after 15-30 s in mice [9]. These results strongly suggest the presence of neurotoxins. Schmidt [22] and Zlotkin [23] provide thoughtful discussions on the case for neurotoxins in true bug venoms, noting that the high potency of the venoms and the reversibility of their toxic effects with washing $[6,9,24]$ argues in favour of the presence of neurotoxins. The most direct demonstration of neurotoxins in the venoms of predaceous heteropterans to date is perhaps the discovery that assassin bug venom contains peptides that adopt the inhibitor cystine knot (ICK) structure which is widespread in venom neurotoxins from other animals [25,26]. Neurotoxic activity of these peptides has been demonstrated, revealing that the venoms of predaceous heteropterans and other venomous taxa have evolved along strongly convergent lines (Section 2.2.3) [27,28]. To date, evidence of neurotoxic activity has been obtained from the venoms of just a few families, but the vast majority of heteropteran venoms have never been investigated using techniques capable of identifying and characterising neurotoxins. Neurotoxins may therefore be widespread in the venoms of predaceous true bugs.

In contrast to the predaceous bugs, blood-feeding heteropterans do not require their hosts to be paralysed. Instead, they need to circumvent the haemostatic and sensory processes of the host that normally prevent loss of blood and detection of parasites. Due to their status as ectoparasites on vertebrates and vectors of blood-borne human diseases, the venoms of blood-feeding heteropterans-especially Triatominae and to a lesser degree Cimicidae-have been characterised in much greater detail than those of their predaceous counterparts (Section 2.3). These studies have revealed a multitude of bioactive molecules that specifically target host haemostatic and defence systems, and which have evolved with a high degree of convergence to venom toxins from other blood-feeding animals [29].

\subsection{Evolution of the Heteropteran Venom Apparatus}

All Hemiptera-whether predaceous, haematophagous or phytophagous-feed through a structure called a proboscis or rostrum (Figure 2). The proboscis consists of highly derived mouthparts that enable it to function like a double-barrelled syringe [30-32]. The bulk of the visible proboscis is formed by the labium, greatly elongated and concave dorsally (with proboscis extended) so that it forms a hollow tube or sheath. Within this sheath lie the mandibles and maxillae, also greatly elongated into structures known as stylets (Figure $2 \mathrm{a}-\mathrm{c}$ ). The mandibular stylets lie outside the maxillary pair, do not interlock, and are often tipped with barbs or serrated edges. The inner maxillary stylets are asymmetric and (with very few exceptions) interlock to form two separate fluid canals: the food canal dorsally, and the salivary canal ventrally (Figure 2c). A devoted muscle-driven pump within the head powers transmission of fluid through each canal. The salivary pump-situated at or close to the 
junction of the maxillary salivary canal with the two ducts from the labial gland complex on each side of the body-pumps fluid from the labial glands into the food source.

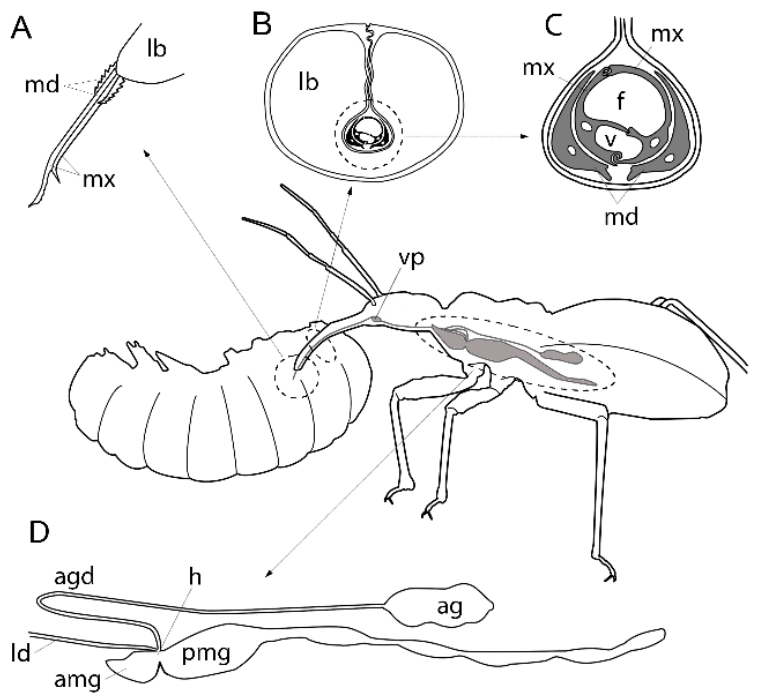

Figure 2. The heteropteran venom apparatus. The central figure shows the position of key anatomical structures involved in envenomation, in this case for prey capture by a reduviid. For clarity, although lateral ducts from venom glands on each side of the body would merge into a common duct shortly before reaching the venom pump (vp), only the left venom gland complex is illustrated. (A) Insertion of mouthparts into the prey, showing mandibular (md) and maxillary (mx) stylets emerging from the tip of the labium (lb); (B) Cross-section of the proboscis showing the labium surrounding the stylet bundle; (C) Enlarged cross-section of mandibular and maxillary stylets. Note the asymmetry of the maxillary stylets and separate food (f) and venom (v) canals. The small hole in each stylet indicates the position of a nerve process; (D) Labial gland complex showing anterior lobe of the main gland (amg), posterior lobe of the main gland (pmg) and accessory gland (ag). The lateral duct (ld) leading to the salivary pump and proboscis, and the accessory gland duct (agd) connecting to the accessory gland meet the main gland at the hilus (h). Adapted from Cobben [30], Cohen [31], and Smith [32].

The most common arrangement of the labial glands consists of a main secretory gland with 2-4 lobes, which may extend anteriorly into the head and posteriorly into the abdomen, and an accessory gland (typically located in a more posterior and medial position, often in close apposition to the gut; Figure $2 d$ ) $[12,33,34]$. The paired main glands are connected to the salivary pump via lateral and common salivary ducts, with the accessory gland being connected to the main gland through an additional duct. Numerous variations to this structure occur, even within a single subfamily $[12,35,36]$. The anterior and posterior lobes of the main gland, and the ducts leading to the accessory gland and the venom/salivary pump, are connected at a complex junction called the hilus. The hilus incorporates an outer and inner mixing chamber that are separated by muscle-controlled valves from each other, from the main gland, and from the efferent duct to the salivary pump $[12,35,37]$. This anatomical arrangement probably allows the animal to inject the contents of each of the lobes of the main gland and the accessory gland separately.

The main gland typically consists of a single layer of columnar secretory epithelium arranged in a sack-like structure surrounding a large glandular lumen. The columnar cells show extensive endoplasmic reticulum and they are usually observed to be filled with dense secretory granules, consistent with them being the major site of protein production and secretion via a merocrine mechanism $[12,35]$. The secretory cells are ensheathed in a basal lamina containing muscle fibres, which receive innervation from the hypocerebral ganglion [12]. The accessory gland is usually observed to contain a watery secretion, is well-oxygenated by a special tracheal supply (suggesting high metabolic turnover), but is not innervated. It is usually postulated to have a role in transporting water from the 
haemolymph to supply the labial glands [38], but it also has a secretory role in some species [39,40]. Though the mechanism of water transport is unknown, some experiments suggest that haemolymph proteins and other solutes may be co-transported into the gland lumen [41].

In phytophagous heteropterans and non-heteropteran hemipterans, the labial glands secrete substances that facilitate feeding by breaking down plant tissue, evading host plant defences, and producing salivary sheaths [42]. In predaceous and blood-feeding heteropterans, the labial glands secrete venom that facilitates feeding by paralysing and liquefying prey through EOD or that combat host haemostatic systems. Radiolabelling experiments have shown that heteropteran venoms originate not in the gut (as in many other arthropods that practice EOD) but solely in the labial glands [20,31]. For venomous species, we propose that the terms venom canal and venom pump are appropriate to use in place of salivary canal and salivary pump. Although the exact function of each labial gland structure is currently uncertain, we also use the term venom gland interchangeably with salivary gland and labial gland.

Predaceous heteropterans ambush, stalk or actively chase their prey. Some species have specialised structures or behaviours that assist in prey capture, including raptorial forelegs and/or adhesive pads (see Sections 2.1.1 and 2.2.1). As the prey or host becomes close, the proboscis is extended. Envenomation typically occurs in a swift strike in which the mandibular and maxillary stylets penetrate the food source and venom is injected, sometimes accompanied by grasping or gripping with the forelegs or fore- and mid-legs. Within this quick movement the sheath-like labium, its tip covered with chemo- and mechanoreceptors, is pressed to the surface of the food source; the pointed tips of the mandibular stylets extend to cut into the prey and anchor it to the predator [30-32]; and the maxillary stylets extend into the prey, injecting venom. Once venom injection has induced paralysis or death [6,9], feeding typically occurs over a period of several minutes to several hours. During this process the stylets may extend deep into the prey, distributing liquefying venom, macerating the prey, and sucking up fluid food [31]. These actions are facilitated by the supremely agile nature of the stylets, which are innervated structures able to turn up to $180^{\circ}$ to access deep cavities of the legs and antennae [31,32]. In blood-feeders such as Rhodnius prolixus, venom is injected continuously throughout feeding [32]. As the maxillary stylets probe tissue for blood vessels, they sample the surrounding material. The presence of ATP (an abundant component of red blood cells) induces them to gorge [43].

Phytophagous heteropterans produce different secretory products within different parts of the labial gland complex [44,45], and some experiments indicate that the glands of predatory heteropterans are also functionally compartmentalised. Haridass and Ananthakrishnan [35] prepared separate homogenates from the main gland anterior lobe, main gland posterior lobe, and accessory glands of two predaceous reduviids (Peirates affinis and Haematorrhophus nigroviolaceus). Injecting homogenates of main gland anterior lobes into prey insects resulted in rapid paralysis, whereas injection of posterior lobe homogenate resulted in no immediate effects but death after several hours. Injection of the accessory gland homogenate had no effect. These authors concluded that the anterior and posterior lobes are specialised to secrete neurotoxins and digestive enzymes, respectively. Other authors have reported similar findings, albeit usually with less drastic differences between the two lobes of the main gland [46,47]. Only Edwards [6] observed no difference between the effects of homogenates from anterior and posterior lobes of $P$. rhadamanthus applied to cockroach heart-dorsum preparations. This contrasting finding may represent either a taxon-specific difference or an effect of dosing. Thus, more detailed studies are required to clarify if assassin bug labial glands, and those of other predaceous heteropterans, are functionally compartmentalised like the venom glands of cone snails [48] and centipedes [49].

\subsection{Diversification of Trophic Strategies in the Heteropteran Radiation}

The highly derived mouthparts and labial glands of hemipterans-originally adaptations to feed on plants-are powerful preadaptations for the development of envenomation. Envenomation 
is practised even by some obligate plant-feeding Sternorrhyncha (soldier aphids; [50]), but it is the heteropterans, whose ancestors switched to a predatory trophic strategy, that the vast majority of venomous hemipterans belong (Figure 3).

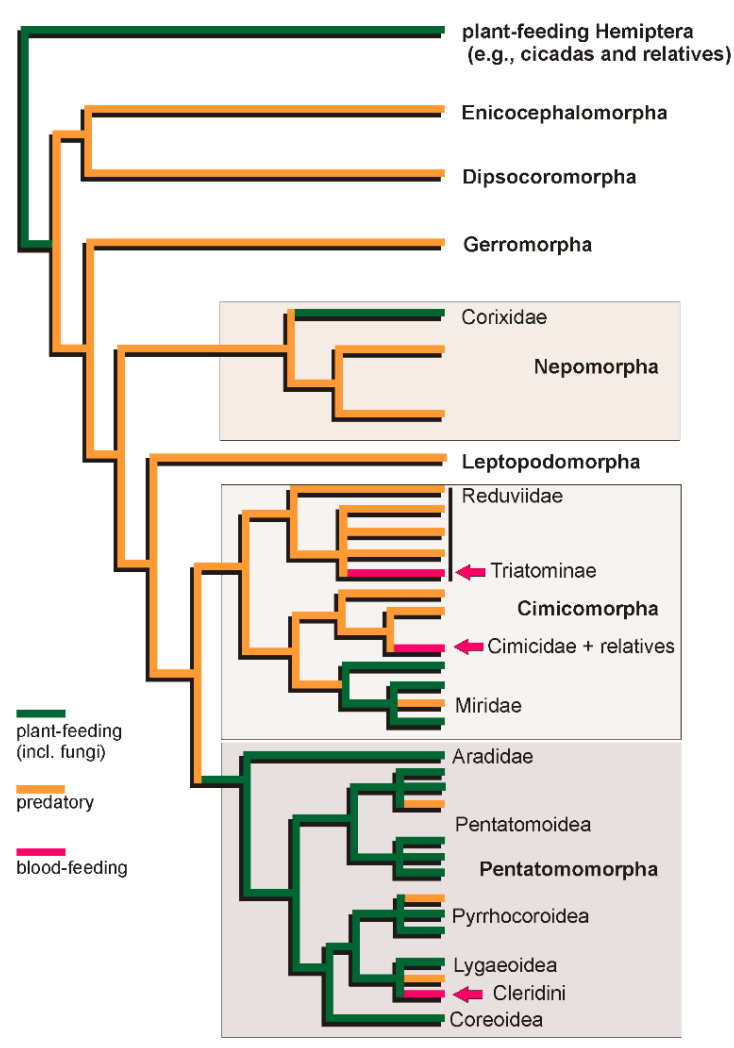

Figure 3. Phylogram showing trophic strategies (phytophagous, predatory, and blood-feeding) across Heteroptera. Phylogenies simplified and modified from Wang and colleagues [51], Schuh and colleagues [52], and Hua and colleagues [53].

Our understanding of the evolution of the different feeding types in Heteroptera has been hampered by the lack of well-supported phylogenetic hypotheses across the suborder, although some general patterns are well-established. Phylogenetic resolution and support amongst the infraorders Enicocephalomorpha, Dipsocoromorpha, Gerromorpha and Nepomorpha that we here refer to as "Lower Heteroptera" [2,51,54] are currently ambiguous. Nevertheless, all four lineages are almost exclusively composed of predators, lending support to the hypothesis that the last common ancestor of Heteroptera was likely also predaceous [55,56]. This predatory life-style appears to have been retained in the last common ancestors of Leptopodomorpha (shore bugs end relatives) and Cimicomorpha (assassin bugs, bed bugs, plant bugs and relatives), but a transition to mycophagy and/or phytophagy occurred in the common ancestor of Pentatomomorpha (stink bugs and relatives), with a reversal to predation in some pentatomomorphan groups. The largest clade of predominantly phytophagous heteropterans, the Miroidea (plant bugs and relatives), represents a secondary transition to plant-feeding within Cimicomorpha. In addition, obligate blood-feeding has evolved at least three times independently within Cimicomorpha (Cimicidae and Polyctenidae; triatomine Reduviidae) and Pentatomomorpha (Rhyparochromidae: Cleradini and Udeocorini) [56].

The radiation of venomous heteropterans into diverse trophic strategies has resulted in different selection pressures acting on venom toxins. Extant true bugs have venoms that are adapted to the way they hunt, feed and defend themselves. In addition to this "passive" evolution of venom toxins, evolutionary innovations in venom systems may be active drivers of evolution, allowing the invasion of new niches and habitats. For example, the highly sophisticated molecular machinery 
underlying the hypermutation of cone snail venom peptides [57,58] has likely driven the recent explosive radiation of the marine snail genus Conus and the adoption of new trophic niches such as feeding on fish [59]. Therefore, studying heteropteran venom systems and venom biochemistry may assist our understanding of their evolutionary radiation. In the next section, we review the major groups of venomous heteropterans and explore how venom pharmacologies have been adapted to facilitate particular feeding strategies.

\section{Diversification of Venom Pharmacology in the Evolution of Heteroptera}

\subsection{Aquatic and Semi-Aquatic Hunters: Nepomorpha, Gerromorpha and Leptopodomorpha}

\subsubsection{Habitat and Prey Range}

Several groups of true bugs are associated with water. The Nepomorpha (true water bugs), Gerromorpha (semiaquatic bugs) and Leptopodomorpha (shore bugs) account for most of the species not contained within the speciose terrestrial infraorders Cimicomorpha and Pentatomomorpha. As their name suggests, the true water bugs spend most of their lives submerged, with the exception of the Gelastocoridae (toad bugs) and Ochteroidea (velvety shore bugs), which like the Leptopodomorpha, occupy freshwater shore zones and some terrestrial habitats [56]. Gerromorpha such as pond skaters, that hunt suspended upon the surface tension of the water, are one of the few insect groups that successfully exploits marine environments.

The giant water bugs and water scorpions (Nepoidea $=$ Belostomatidae + Nepidae) are ambush predators that typically await prey in submerged vegetation [56]. Raptorial forelegs occur in Gerromorpha and the nepomorphan families Belostomatidae, Gelastocoridae, Nepidae, Naucoridae and Notonectidae. Plant-feeding is rare in aquatic and semi-aquatic Heteroptera, having evolved apparently only in the water boatmen (Corixidae) [56]. The most common prey items consumed are aquatic crustaceans, insects, snails, worms, tadpoles, and small fish. Various aquatic heteropterans are regarded as biocontrol agents in natural and disturbed aquatic environments, especially for larvae of disease-vectoring mosquitoes [60-63]. Some giant water bugs (Belostomatidae) grow to be very large (10-12 cm) and have been recorded killing vertebrates including frogs, turtles, snakes and birds [64-67]. From a pharmacological point of view, this prey range is interesting as it suggests belostomatid venom may contain toxins selected for bioactivity against vertebrate molecular targets.

\subsubsection{Activity and Composition of Nepomorphan Venoms}

Aquatic and semi-aquatic heteropterans inject venom to immobilise and liquefy prey. Most information regarding the venoms of the water-associated groups is from Belostomatidae, Nepidae and Notonectidae, while essentially nothing has been recorded of the venoms of Gerromorpha or Leptopodomorpha. Humans bitten by aquatic water bugs experience pronounced pain, swelling, vasodilation and sometimes numbness [7] while invertebrates and small vertebrates bitten by belostomatids or injected with their venom are typically paralysed after several minutes [24,68]. Venom gland extracts equivalent to $1 \%$ of the glands of the creeping water bug Naucoris cimicoides dissolved in $100 \mu \mathrm{L}$ saline result in immediate cessation of beating of the cockroach heart-dorsum preparation [6]. Venom from the giant water bug Belostoma anurum similarly prevents pumping of the heart-dorsum of the triatomine $R$. prolixus, and reduces the amplitude of rat sciatic nerve compound action potentials; both these effects were reversible and mediated by low-molecular weight compounds $(<5 \mathrm{kDa})$ that are not destroyed by proteases [69]. Belostomatid venom injected into guinea pig hearts causes bradychardia and an increase in resting tension not mediated through effects on cholinergic receptors or $\mathrm{Ca}^{2+}$ channels [70]. Picado [24] found that bites from Belostoma delpontei paralyse frogs within several minutes. Diluted whole-head homogenates produce a reversible paralysis in fish $15 \mathrm{~min}$ after being introduced to the water in which they were swimming. 
The detailed composition of belostomatid venom is unknown, but electrophoresis of the venom reveals many protein components ranging from low molecular weight peptides $(<5 \mathrm{kDa})$ up to proteins $\sim 55 \mathrm{kDa}$ in size $[39,70,71]$. Enzymatic assays (Table 1) have revealed phospholipase $\mathrm{A}_{2}$, hyaluronidase, protease, amylase, esterase, $\alpha$-glucosidase, glucosaminidase, invertase, lipase, nuclease, phosphatase and phosphohydrolase activities [39,68,71,72]. Of these, phospholipase $A_{2}$ and hyaluronidase are of particular interest because they have been convergently recruited into phylogenetically diverse animal venoms [11]. Venom phospholipase $A_{2}$ toxins bind with high affinity to sites on synaptic clefts and muscles, where they exert toxic effects through enzymatic cleavage of membrane glycerophospholipids to yield lysophospholipids and free fatty acids (both potent physiological modulators); they may also act through non-enzymatic mechanisms [73,74]. In contrast, hyaluronidase has been proposed to be a "spreading factor" that increases the permeability of tissue to other toxins [75]. Water scorpion (Nepidae) venom has not been examined in terms of its protein content or bioactivity, but a transcriptomic study of salivary glands from Ranatra chinensis revealed many transcripts encoding proteins with homology to proteases, acid phosphatases, apyrases, dipeptidylpeptidases IV, hyaluronidases, and prophenyloxidases [76]. Aside from protein components, Silva-Cardoso and colleagues [68] reported a rich lipidic content of venom from the giant water bug B. anurum, which was found to contain $88 \%$ lipid and only $12 \%$ protein. These authors focused on the presence of lysophosphatidylcholine (lysPC) in water bug venom. LysPC is a product of the degradation of phosphatidylcholine by phospholipase $\mathrm{A}_{2}$, and has been shown to have a variety of toxic effects including inhibition of neurotransmitter release and vasodilation [77,78]. LysPC accounted for approximately $1.8 \%$ of the venom, and venom-purified lysPC and unpurified venom containing an equivalent amount of lysPC were found to cause paralysis when injected into zebrafish (Danio rerio).

Aside from the small number of studies on the venom of aquatic bugs, an additional complication arises from the complexity of the secretory glands in this group. As well as the normal complement of main labial glands with anterior and posterior lobes and accessory glands, the belostomatids, nepids and gelastocorids contain additional secretory glands-termed by various authors "cephalic", "maxillary", or "poison" glands-that lie ventrally in the head or anterior thorax $[79,80]$. These glands are unconnected to the labial/venom glands, and they open not into the venom canal of the proboscis but into two ventrolateral slits near the base of the proboscis. Their precise role is unclear, but insects expel a "milky" secretion from these glands when threatened or handled that is potently insecticidal [79] and produces a burning sensation if applied to a puncture in human skin [80]. This secretion may perform a defensive function. Thus, it is important that future studies clarify if the "white and viscous" lipid-rich venom characterised by Silva-Cardoso and colleagues [68] corresponds to the "milky" secretion produced in the cephalic glands, or to the venom injected into prey that is produced by the labial glands.

\subsection{Assassin's Creed: Terrestrial Predators in Cimicomorpha and Pentatomomorpha}

\subsubsection{Efficient Predation through Envenomation, Prey-Capture Organs and Dietary Specialisation}

Many species of the higher Heteroptera are efficient terrestrial predators. Envenomation, which allows swift killing of prey many times larger in size than the predator-together with quick lifecycles, active hunting behaviours on plants and trees, and dietary preferences that are either broad or actively favour plant-damaging prey-make many predatory heteropterans excellent biocontrol agents in agricultural systems compared to other venomous animals. For example, single big-eyed bugs (Geocoris punctipes) or assassin bugs (Pristhesancus plagipennis) are respectively capable of consuming 1600 spider mites or 220 cotton bollworms through the nymphal stages alone [81,82]. Numerous methods for the mass rearing of heteropteran predators have been developed using artificial diets [83], and representatives of the Anthocoridae, Nabidae, Miridae, Pentatomidae, and Reduviidae are in active commercial use $[10,83]$. 
Table 1. Enzymes detected in venoms of predaceous heteropterans.

\begin{tabular}{|c|c|c|c|c|c|c|c|c|c|c|c|c|c|c|c|c|c|c|}
\hline \multirow[b]{2}{*}{ Infraorder } & \multirow[b]{2}{*}{ Family } & \multirow{2}{*}{ Species } & \multirow{2}{*}{$\begin{array}{l}\text { Feeding } \\
\text { Strategy } \\
\quad \mathrm{a}\end{array}$} & \multirow{2}{*}{$\begin{array}{c}\text { Phospholipase } \\
\mathbf{A}_{2}\end{array}$} & \multirow{2}{*}{ Hyaluronidase } & \multicolumn{4}{|c|}{ Protease } & \multirow[b]{2}{*}{ Lipase } & \multirow[b]{2}{*}{ Esterase } & \multirow[b]{2}{*}{ Invertase } & \multirow[b]{2}{*}{ Nuclease } & \multirow{2}{*}{$\begin{array}{c}\text { Acid } \\
\text { phosphatase }\end{array}$} & \multirow{2}{*}{$\begin{array}{c}\text { Alkaline } \\
\text { phosphatase }\end{array}$} & \multirow[b]{2}{*}{ Amylase } & \multirow[b]{2}{*}{ Pectinase } & \multirow[b]{2}{*}{ Refs. } \\
\hline & & & & & & $\begin{array}{c}\text { Trypsin- } \\
\text { like }\end{array}$ & $\begin{array}{l}\text { Chymotrypsin- } \\
\text { like }\end{array}$ & Aminopeptidase & Carboxypeptidase & & & & & & & & & \\
\hline \multirow{3}{*}{ Nepo-morpha } & Belostomatidae & $\begin{array}{l}\text { Lethocerus } \\
\text { sp. }\end{array}$ & $\mathrm{P}$ & & yes & yes & yes & & & yes & yes & & yes & yes & yes & no & & {$[39,71]$} \\
\hline & Belostomatidae & $\begin{array}{c}\text { Belostoma } \\
\text { sp. }\end{array}$ & $\mathrm{P}$ & yes & & yes & yes & & & yes & $?$ & no & & yes & yes & $?$ & & {$[39,68,72]$} \\
\hline & Nepidae & $\begin{array}{l}\text { Ranatra } \\
\text { elongata }\end{array}$ & $\mathrm{P}$ & & & & & yes & & no & no & yes & & & & no & & [72] \\
\hline \multirow{10}{*}{ Cimicomorpha } & Reduviidae & $\begin{array}{c}\text { Platymeris } \\
\text { rhadamanthus }\end{array}$ & $\mathrm{P}$ & yes & yes & yes & & & & no & no & & & & & & & {$[6,42]$} \\
\hline & Reduviidae & $\begin{array}{c}\text { Zelus } \\
\text { renardii }\end{array}$ & $\mathrm{P}$ & strong & & strong & yes & weak & weak & & & & & & & weak & & {$[31,84,85]$} \\
\hline & Reduviidae & $\begin{array}{c}\text { Sinea } \\
\text { confusa }\end{array}$ & $\mathrm{P}$ & strong & & strong & & & & & & & & & & weak & & {$[31,85]$} \\
\hline & Reduviidae & $\begin{array}{l}\text { Rhynocoris } \\
\text { marginatus }^{c}\end{array}$ & $\mathrm{P}$ & yes & yes & strong & & weak & & yes & yes & yes & & yes & yes & yes & & [86-88] \\
\hline & Reduviidae & $\begin{array}{l}\text { Catamiarus } \\
\text { brevipennis }\end{array}$ & $\mathrm{P}$ & & & yes & & & & yes & & yes & & & & yes & & [87] \\
\hline & Anthocoridae & $\begin{array}{c}\text { Orius } \\
\text { insidiosus }\end{array}$ & $\mathrm{P}$ & & & yes & & & & & & & & & & yes & & [89] \\
\hline & Nabidae & $\begin{array}{c}\text { Nabis } \\
\text { alternatus }\end{array}$ & $\mathrm{P},(\mathrm{H})$ & yes & & yes & & & & & & & & & & $?$ & & {$[31,85]$} \\
\hline & Miridae & $\begin{array}{c}\text { Deraeocoris } \\
\text { sp. }\end{array}$ & $\mathrm{P}$ & yes & & yes & yes & & & & & & & & & & $?$ & {$[85,90]$} \\
\hline & Miridae & Lygus sp. & $\mathrm{H},(\mathrm{P})$ & $?$ & no & yes & yes & & & & & & & & & strong & yes & {$[85,91-94]$} \\
\hline & Miridae & $\begin{array}{c}\text { Creontiades } \\
\text { dilutus }\end{array}$ & $\mathrm{H},(\mathrm{P})$ & & & weak & yes & & & & & & & & & & yes & {$[95,96]$} \\
\hline \multirow{3}{*}{$\begin{array}{l}\text { Pentatom- } \\
\text { omorpha }\end{array}$} & Pentatomidae & Podisus sp. ${ }^{\mathrm{d}}$ & $\mathrm{P}$ & $?$ & & yes & & & & & & & & yes & & yes & & {$[31,85,97-99]$} \\
\hline & Pentatomidae & $\begin{array}{l}\text { Andrallus } \\
\text { spinidens }\end{array}$ & $\mathrm{P}$ & & & yes & yes & yes & yes & & & & & & & & & [100] \\
\hline & Geocoridae & $\begin{array}{c}\text { Geocoris } \\
\text { punctipes }\end{array}$ & $\mathrm{P},(\mathrm{H})$ & yes & & yes & & & & yes & & & & & & $?$ & & {$[31,85,92]$} \\
\hline
\end{tabular}

${ }^{a} \mathrm{P}=$ predator, $\mathrm{H}=$ herbivore, brackets indicate facultative feeding. ${ }^{\mathrm{b}}$ Swart and colleagues [39] found additional enzymatic activities in belostomatid venoms including glucosidase, $\mathrm{N}$-acetylglucosamidase, and leucine arylamidase. ${ }^{\mathrm{c}}$ Sahayaraj and colleagues [88] also found trehalase activity in Rhynocoris marginatus venom. ${ }^{\mathrm{d}}$ Fialho and colleagues also found collagenase and cathepsin-L-like activity in the venom glands of Podisus nigrispinus. "Strong" or "weak" indicate activity strength as determined in the original studies while "yes" and "no" indicate simple presence or absence. A question mark indicates conflicting results between studies or species differences within a genus. 
Besides envenomation, predation is assisted by a variety of morphological and behavioural adaptations. One such adaptation is the fossula spongiosa, an adhesive structure on the fore and sometimes middle tibia of many cimicomorphans used for gripping the prey [101]. This structure was recently shown to have been part of the ancestral raptorial leg of Reduviidae and was lost multiple times during the radiation of assassin bugs (Figure 4) [52]. Various lineages of reduviids subsequently evolved alternate methods for holding on to prey [102]. For example, in a group of harpactorine Reduviidae that includes the large and widespread genus Zelus (leafhopper bugs), bioadhesives are secreted from glands on the fore- and mid-legs [103,104]. The resin bugs (tribes Apiomerini, Diaspidiini, and Ectinoderini, also in the subfamily Harpactorinae) collect sticky plant resins which are applied to the forelegs to assist prey capture [105] — a behaviour that has recently been shown to have arisen independently in each group [106]. Raptorial forelegs with enlarged femora and/or heavy armature on the ventral surfaces of foretibia and forefemur occur in other lineages of Reduviidae, including the ambush bugs (Phymatinae) and thread-legged bugs (Emesinae) [107,108]. In venomous groups such as scorpions, coevolution of venoms and grasping forelegs (pincers) has occurred such that the two systems are complementary [109]. A similar trend may occur in Heteroptera, as assassin bugs lacking a fossula spongiosa have been reported to take less time to paralyse prey $[110,111]$.

Venom toxicity and specificity is likely also to vary with prey preference. Many heteropteran predators are generalists, feeding on a wide range of prey, and generalism is probably the ancestral condition [112]. Some heteropterans display more restrictive prey choices, such as prostemmatine Nabidae on other Heteroptera [113] or isometopine Miridae on scale insects [114]. Many of the prey specialists currently documented occur in Reduviidae (Figure 4). Prey specialisation has frequently been accompanied by the evolution of specialised morphological and behavioural adaptations. For example, some lineages of the thread-legged bugs (Reduviidae: Emesinae) are facultatively or obligately associated with spider-webs, where they either steal prey captured in the spider's webs or prey on the spiders themselves $[115,116]$. Araneophagic emesine bugs have evolved convergently to araneophagic spiders [117] in developing a form of aggressive mimicry in which plucking of web strands is used to produce vibrations that manipulate the behaviour of the prey spider [118-121]. The feather-legged bugs (Holoptilinae) specialise on ants and employ both visual and chemical luring strategies [122,123]. Juveniles attract prey by waving their hind legs, which are covered in a cluster of brush-like setae. Despite the dangerous nature of their prey-which are many times larger and possess their own insecticidal venom - the bugs only strike when actually grasped in the ant's mandibles [124]. Adult feather-legged bugs possess an even more powerful luring system, secreting a pheromone from a ventral organ called a trichrome $[125,126]$. This pheromone attracts, apparently mesmerises, and may paralyse ants. After typically a long period of time crawling around and over the assassin, the ants are eventually killed when they attach their jaws to the trichrome itself-a position placing the vulnerable area at the base of its head directly below the assassin's feeding proboscis. Prey conservatism on specific groups of termites has been documented using forensic and crowd-sourcing methods for assassin bugs in the subfamilies Salyavatinae and Sphaeridopinae [127]. Members of one genus in the subfamily Salyavatinae have been shown to "fish" for their prey with just-fed-upon termite carcasses to catch workers assiduously trying to retrieve the bodies of their dead [128]. Prey specialisations have evolved independently to those listed above in the Ectrichodiinae for millipedes [129]; in Cetherinae [130], the harpactorine genera Tegea [131] and Micrauchenus [132], and the reduviine genus Leogorrus [130] for termites; in some members of the reduviine Acanthaspis clade [133] for ants; and in the harpactorine genera Scipinia and Nagusta for social jumping spiders [134].

While a small amount is known about the morphological and behavioural adaptations accompanying prey specialisation in heteropterans, almost nothing is known about the accompanying changes in venom composition. The multiple independent instances of prey specialisation among the assassin bugs suggests they are a potential source of prey-specific toxins, which are of interest for biotechnology [135]. Further study of assassin bug venom may also offer an opportunity to contribute 
to discussions of how the evolution of prey specialisation and capture organs such as raptorial forelegs affects venom composition [110,136-139].

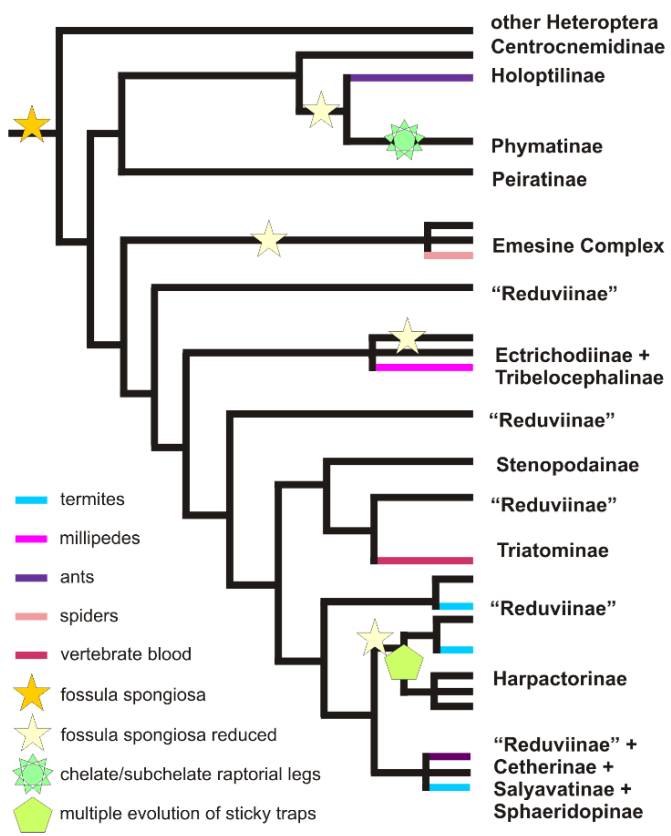

Figure 4. Prey specialisations and raptorial leg modifications within Reduviidae. Modified and simplified from Hwang and Weirauch [112], Gordon and Weirauch [127], and Zhang and colleagues [106].

\subsubsection{Physiological Effect of Venoms of Terrestrial Predaceous Heteropterans}

\section{Effects of venom on invertebrates}

Predaceous cimicomorphans and pentatomomorphans use their venoms primarily for immobilising, killing, and liquefying invertebrate prey. A key effect of venoms is rapid paralysis, which has been reported after envenomation by members of the Reduviidae [6,9,35,140], asopine Pentatomidae [141], predaceous Miridae [85], and predaceous Lygaeidae [142], and which may be much more widespread. The insecticidal activities of two reduviine assassin bug venoms have been quantified as $\mathrm{LD}_{50}$ values of (dry weight of venom) $2 \mathrm{mg} / \mathrm{kg}$ (H. innesi venom injected into larvae of the fly Sarcophaga argyrostoma) [9] or $10.25 \mathrm{mg} / \mathrm{kg}$ (P. rhadamanthus venom injected into the cockroach $P$. americana) [6]. Insecticidal activity has also been demonstrated in the venoms of harpactorine (Rhynocoris sp.) and peiratine (Catamiarus brevipennis) assassin bugs, but with doses that are likely substantially higher $(2-9 \mu \mathrm{L}$ of crude venom per gram of insect tissue) $[46,111,140,143]$. While Edwards [6] found that P. rhadamanthus venom had no effect when applied topically or orally to flies and cockroaches, both Sahayaraj and Muthukumar [143] and Sahayaraj and Vinothkanna [143] found that adding venom of Rhynocoris sp. diluted approximately 1:1000 to the feed of caterpillars over $96 \mathrm{~h}$ was sufficient to cause death.

The effects of reduviid venom have also been studied on isolated insect nerve preparations. Edwards [6] found that adding undiluted P. rhadamanthus venom to cockroach heart-dorsum preparation induces violent contracture of the heart and surrounding musculature, immediate cessation of beating, and a slow relaxation of excitable tissue. Diluted venom, down to one part in a million, resulted in initial increases in heart rate followed by irregular beating and eventually cessation. Similar results were obtained with venom from the predatory reduviids Rhynocoris carmelita (Harpactorinae) and Reduvius personatus (Reduviinae). In contrast, the venoms of blood-feeding reduviids (Triatoma protracta and Rhodnius prolixus) showed no effect, and venoms from lygaeid bugs with phytophagous or facultatively predaceous lifestyles showed much weaker modulation 
of heart-dorsum pumping at much higher doses. Venom from P. rhadamanthus induced burst firing followed by non-responsiveness in cockroach giant fibres, loss of conduction in non-synaptic preparations from the locust Schistocerca gregaria, and general lytic activity on all body tissues. Edwards concluded that the major action of assassin bug venom is non-specific disruption of lipid membranes, but the high potency of the venom and the observation that heart-dorsum preparations from $P$. rhadamanthus are immune to the bug's own venom suggest the additional presence of neurotoxins.

\section{Effects of venom on vertebrates}

In addition to prey capture and feeding, many species use venom for defence and will envenomate humans if handled. The minute pirate bugs (Anthocoridae) owe their name to the disproportionate amount of pain their bites induce relative to their small size (1-5 mm). Some assassin bugs such as the reduviine $P$. rhadamanthus also spit venom defensively [144]. This behaviour is apparently directed at vertebrate predators and has arisen convergently to similar behaviour in snakes, spiders and wasps [145,146]. Most heteropteran envenomations are not medically important for humans. The most common symptoms are pain, redness, and swelling. However, envenomations by some species induce respiratory disturbances and tissue necrosis [6]. At least one species, the "afrur" (H. innesi), a reduviine assassin bug occurring in the Middle East, is suspected of being responsible for several human fatalities by envenomation [5].

Zerachia and colleagues $[9,147]$ characterised the effect of $H$. innesi venom on mammalian tissues. Surprisingly, venom from this bug is more toxic to mice (LD $\operatorname{Li}_{50} 1 \mathrm{mg} / \mathrm{kg}$ ) than to fly larvae (LD50 $2 \mathrm{mg} / \mathrm{kg}$ ). Toxicity testing of size-fractionated venom indicated the factors causing insect toxicity co-purified with cytolytic activity while the factors causing mammalian toxicity eluted later [23]. A single envenomation is capable of killing a mouse in 15-30 s, apparently through respiratory paralysis [9] and a cytolytic component capable of lysing red blood cells is also present [147]. Sub-lethal doses of venom induce paralysis and local haemorrhage when injected intramuscularly, nocifensive behaviour when injected intraperitoneally, and reduced blood pressure and peripherally-restricted haemorrhage when injected intravenously [9]. Venom applied to rabbit cornea induced lacrimation, blinking and hyperaemia, while guinea pigs inhaling aerosols containing venom died due to respiratory paralysis. Low concentrations of venom caused slow contraction of guinea pig ileum preparations and blocked acetylcholine-induced contractions in a reversible manner. Injection of venom into the femoral artery of a cat completely and reversibly blocked contraction of the gastrocnemius muscle in response to sciatic nerve stimulation, similar to the action of the nicotinic acetylcholine receptor antagonist curare [9]. These effects suggest the presence of an acetylcholine receptor antagonist and perhaps sodium channel modulators. Thus, venoms from assassin bugs in general, and $H$. innesi in particular, are likely to contain neurotoxic molecules capable of modulating the activity of channels and receptors in the mammalian nervous system [148].

\subsubsection{Composition of Venoms from Terrestrial Predators.}

Much of what is known about venoms from terrestrial predaceous heteropterans is from one family, the assassin bugs (reviewed by [149]). Edwards [6] recorded the $\mathrm{pH}$ of $P$. rhadamanthus venom as 6.8 , which is similar to the $\mathrm{pH}$ of labial gland lumens (6.0-6.8; [12]). Sahayaraj [88] observed a decrease in $R$. marginatus venom $\mathrm{pH}$ from 7.4 one day after feeding to 5.1 after seven days starvation. Infrared spectra of dried $R$. marginatus venom suggests it consists predominantly of protein [88]. The protein content of assassin bug venom depends on species, sex, time since emergence or feeding, and the gland lobe in which venom is produced $[6,46,88,150,151]$. Sahayaraj and colleagues [151] examined venoms from bugs fed the previous day, finding protein concentrations of 24 and $54 \mathrm{mg} / \mathrm{mL}$ respectively for males and females of $R$. marginatus, and 28 and $86 \mathrm{mg} / \mathrm{mL}$ for males and females of C. brevipennis. Ambrose and Maran [150] and Maran [46] compared the concentration of venom extracted from each lobe of the main glands of Acanthaspis pedestris and Rhynocoris sp. respectively (without homogenisation of gland tissue) after feeding and over each day of prey deprivation. Interestingly, the contents of 
the anterior lobe were consistently more concentrated than those of the posterior lobe by roughly a factor of two. The concentration of venom from both lobes increased steadily up to eight days starvation. In A. pedestris, the protein concentration increased from 155 to $224 \mathrm{mg} / \mathrm{mL}$ for the anterior lobe and from 78 to $124 \mathrm{mg} / \mathrm{mL}$ for the posterior lobe. Maximum concentrations of $414 \mathrm{mg} / \mathrm{mL}$ and $201 \mathrm{mg} / \mathrm{mL}$ were reached for the anterior and posterior lobes, respectively, of $R$. kumarii. Sahayaraj and colleagues [88] recorded protein concentrations up to $420 \mu \mathrm{g} / \mathrm{mg}$ wet venom. Thus, assassin bug venom concentrations are in the same range reported for other animal venoms [152,153].

The major classes of toxins present in venoms of predaceous heteropterans are unknown. However, the studies of Corzo and colleagues [28] and Bernard and colleagues [27] revealed that some assassin bug venoms contain disulfide-rich peptide toxins with a high degree of structural convergence to venom peptides from cone snails, scorpions and spiders. In Corzo's study, venoms from three assassin bugs (Agriosphodrus dohrni and Isyndus obscurus, both Harpactorinae; and Peirates turpis, Peiratinae) were fractionated via liquid chromatography. Fractions selected based on their mass spectra were then sequenced via Edman degradation. These methods revealed a homologous peptide in all three bugs that contains 34-36 amino acid residues with a conserved pattern of six cysteine residues (Figure 5) and structural similarity to the $\omega$-conotoxins produced by cone snails. The peptide from P. turpis, Ptu1, was then synthesised in quantity using Fmoc solid phase peptide synthesis. Like the $\omega$-conotoxins, synthetic Ptu1 was shown to inhibit $N$-type voltage-gated calcium channels (Cav2.2) [28] and adopt the ICK fold [27]. A DALI search [154] reveals that the 10 closest structural homologs of Ptu1 are actually ICK toxins from spider venom. The closest sequence/structural homolog is Huwentoxin- $X$ from the tarantula Haplopelma schmidti that, in a striking example of convergent evolution, also targets $\mathrm{Ca}_{\mathrm{V}} 2.2$ (Figure 5). Peptides in similar mass ranges have been observed in venoms from genus Rhynocoris using MALDI-TOF mass spectrometry (MS) [88,155] and may be widespread among reduviids and other predatory heteropterans.
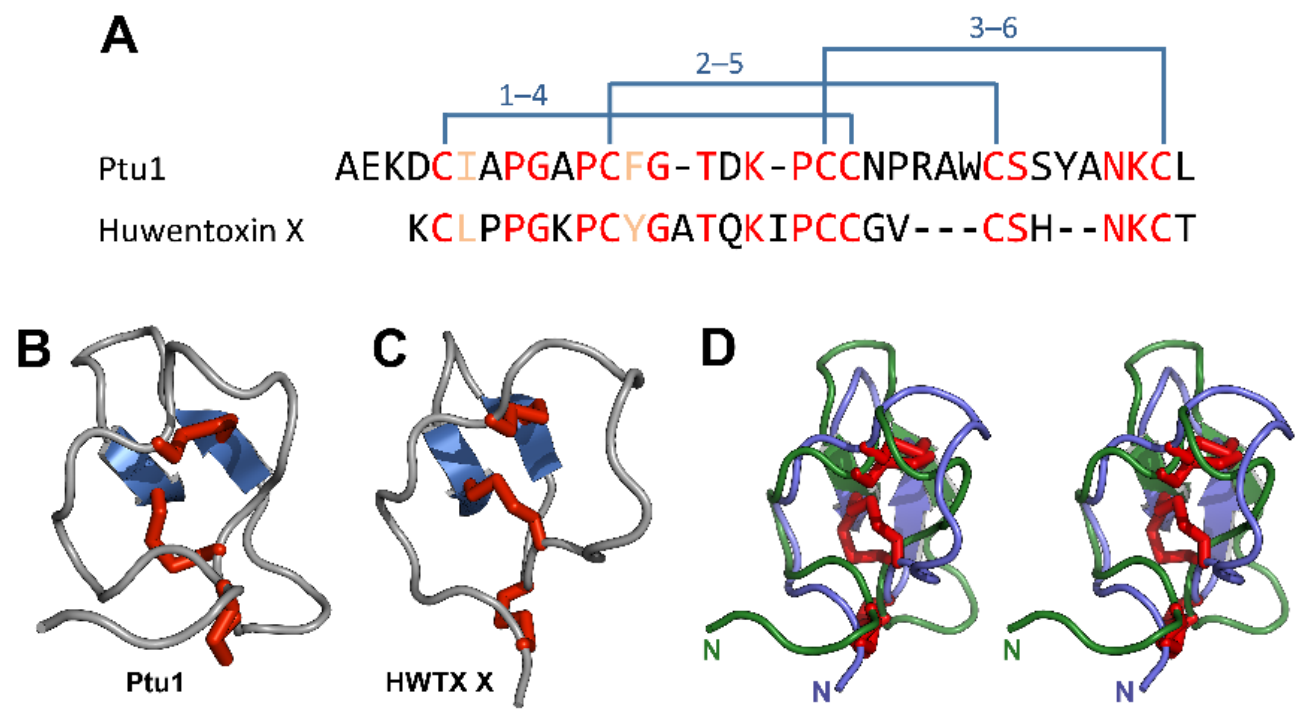

Figure 5. Similarity of ICK toxins from spiders and assassin bugs. (A) Alignment of the amino acid sequences of Ptu1 from venom of the assassin bug Peirates turpis [27] and huwentoxin-X (HWTX-X) from venom of the tarantula Haplopelma schmidti [156]. Identical and similar residues are highlighted in red and orange, respectively, and the disulfide-bond architecture is shown above the sequence alignment. The peptide sequences are remarkably similar ( $50 \%$ identity) and both toxins target $\mathrm{Ca}_{\mathrm{V}} 2.2$ channels; (B, C) Schematic of the 3D structures of Ptu1 (PDB 1I26) and HWTX-X (PDB 1Y29). Disulfide bonds and $\beta$-strands are coloured red and blue, respectively; (D) Stereo view of an overlay of the structures of Ptu1 (green) and HWTX-X (blue). The N-termini are labelled. 
In contrast to these findings, the recent study of Martínez and colleagues [157] found that venom of the predatory stinkbug Podisus nigrispinus is toxic to the caterpillar Anticarsia gemmatalis because it contains small molecule toxins including $N, N$-dimethylaniline and 1,2,5-trithiepane. Insecticidal activity was concentrated in ether extracts rather than aqueous extracts of venom glands, and toxicity was only mildly affected by treatment with either protease inhibitor cocktails or proteinase $\mathrm{K}$. These results suggested that venom toxicity was due to the presence of hydrophobic non-proteinaceous molecules, which were subsequently identified by gas chromatography-MS. Thus, asopine pentatomids such as P. nigrispinus may rely less on peptide and protein toxins for subduing prey compared to their reduviid relations. This difference in toxin composition may be related to the transition to phytophagy and then reversion to predation as a trophic strategy in the ancestors of Asopinae (Section 1.3).

In addition to neurotoxic peptides and non-protein small molecules, venoms from cimicomorphans and pentatomomorphans contain larger protein components that underlie numerous enzymatic activities (Table 1). Sahayaraj and colleagues [88] observed assassin bug (R. marginatus) venom proteins to occur mainly in the range 2-37 kDa, while Habibi and colleagues [158] observed that most venom proteins in spiny soldier bug venom (Pentatomidae: Asopinae) are in the range 15-90 kDa. Phospholipase $\mathrm{A}_{2}$ and hyaluronidase, which are present in the venoms of aquatic heteropterans and many other venomous animals (Section 2.1.2), are prominent in predatory species but not phytophagous species (Table 1).

Other enzymatic activities reported are protease, esterase, lipase, phosphatase, invertase and trehalase (Table 1). These may be most easily ascribed a function in liquefaction, but may also contribute to toxicity. By far the most commonly reported enzymatic activity is proteolytic. In almost all species the primary protease activity is trypsin-like (as determined by an alkaline $\mathrm{pH}$ optimum, substrate and inhibitor specificity) $[6,84-86,90,94,159]$. Cohen [84] observed three different proteins with trypsin-like activity in the salivary glands of Zelus renardii (Harpactorinae), the most prominent of which had a molecular mass around $27 \mathrm{kDa}$. Frequently, lesser amounts of chymotrypsin-like endopeptidase and amino- and carboxypeptidases are present (Table 1). Collagenase activity has also been reported in venom of the predatory bug Podisus nigrispinus [160]. Some omnivorous heteropterans feature enzymes that break down plant-specific biopolymers, such as amylase and pectinase. Surprisingly, low levels of amylase are also detected in obligate predators (Table 1) which may represent relic activity, previously unsuspected omnivory, or the ability to break down the gut contents of herbivorous prey.

The only transcriptomic study of a venom gland from a terrestrial heteropteran predator comes from a minute pirate bug (family Anthocoridae). Baek [161] made a subtractive cDNA library enriched for transcripts expressed at higher levels in the venom glands compared to whole body of the minute pirate bug Orius laevigatus. The most abundant transcripts in this library encoded proteases, haemolysins, carbonic anhydrases, DNAses, lipases, cathepsin B1, alkaline phosphatase, CUB domain proteins, bacterial-permeability-increasing protein and many unknown proteins. Thus, anthocorid venom may have cytolytic activity by virtue of membrane-disrupting proteins such as haemolysins and bacterial-permeability-increasing protein.

\subsection{The Blood Feeders}

\subsubsection{Convergent Evolution of Blood-Feeding in Heteroptera}

Some true bugs have built further on the evolutionary success of predation, becoming ectoparasites feeding on vertebrate blood. The evolution of blood-feeding may have occurred in the nests of birds and mammals, where predaceous bugs attracted by the plentiful invertebrate prey were easily tempted to experiment with haematophagy by the close proximity of helpless vertebrate juveniles [112,162]. Obligate blood-feeding has evolved in Heteroptera several times independently: at least once and perhaps twice or more among the kissing bugs (reduviid subfamily Triatominae) $[163,164]$, and at least once in the ancestors of the bed bugs (Cimicidae) and the closely related bat bugs (Polyctenidae). Several other heteropteran groups have been reported to feed on 
blood to various degrees. Some rhypochromine Rhypochromidae (tribes Cleradini and Udeocorini) practise both facultative blood-feeding from vertebrates and kleptohaematophagy through feeding on engorged haematophages [165-168]. Minute pirate bugs (Anthocoridae) and non-triatomine assassin bugs are occasionally recorded to feed from vertebrates and are sometimes considered facultative blood-feeders (e.g., [164]). For vertebrates, including humans, bites from blood-feeding insects represent not only an annoyance and nutritive drain but also the potential of anaphylactic reactions and contraction of blood-borne diseases. The most important disease vectors in Heteroptera are the kissing bugs that transmit Trypanosoma cruzi, the causative agent of Chagas disease [169]. Because of their status as human disease vectors, the venoms of blood-feeding heteropterans have been studied in much greater detail than those of their predaceous counterparts, and excellent recent reviews are available $[29,170-175]$. This section therefore aims not at comprehensive review but to compare and contrast the venoms of blood-feeding and predaceous heteropterans.

\subsubsection{Venoms of Haematophagous Heteroptera}

Early studies on venom glands from blood-feeding heteropterans established that both the high activity of digestive enzymes and the potent paralytic activity that characterise venom from predaceous heteropterans were lacking [6,12]. Among blood-feeding bugs, paralysing activity has only been reported in the context of facultative entomophagy [176]. These results are consistent with the fundamentally different activities required of venom used to acquire blood meals compared to venom used to subdue and liquefy prey. Since vertebrate hosts are typically many orders of magnitude larger than haematophagous bugs, remaining undetected during feeding presents a better strategy than inducing systemic paralysis. Moreover, already-liquid blood does not require enzymatic liquefaction, as do the tissues of invertebrates. Instead, these blood-feeders have to overcome the sophisticated and highly redundant haemostatic defense systems that protect host tissues from blood loss, invasion and injury - the most important of which are platelet aggregation, vasoconstriction, blood coagulation, and the pain and itch pathways [175].

To achieve this feat, heteropteran blood-feeding bugs have evolved a complex cocktail of pharmacological agents that affect many different components of the haemostatic system at once, simultaneously dilating blood vessels [163,177-179] and inhibiting platelet aggregation [180-183] and coagulation [184-187]. Triatomine venom is also able to inhibit voltage-gated sodium channels [188], which may account for its anaesthetic effect $[189,190]$. Laboratory trials have shown that even alert humans are usually unable to detect triatomine bites if they cannot see the bug [191]. In contrast, without the ability to inject venom (for example when the labial gland complex is ablated), triatomines experience considerable difficulty in obtaining a blood meal even from restrained hosts [192]. 
Table 2. Bioactive components in the venoms of blood-feeding heteropterans.

\begin{tabular}{|c|c|c|c|c|c|}
\hline Molecule & $\begin{array}{l}\text { Protein Family/ } \\
\text { Molecule Class }\end{array}$ & Species & Physiological Function a & Molecular Target & Reference \\
\hline Nitric oxide & Gas & R. prolixus, C. lectularius & V, PAI & Activates guanylate cyclase & {$[193,194]$} \\
\hline Lysophosphatidylcholine & Lipid & Rhodnius prolixus & PAI, other & Unknown & [195] \\
\hline Nitrophorins 1-4 & Lipocalin & Rhodnius prolixus & V, PAI, AI & NO donor, also binds histamine & {$[159,193,196-202]$} \\
\hline Nitrophorin-2 (Prolixin) & Lipocalin & Rhodnius prolixus & AC, V, PAI, AI & Additionally inhibits Tenase complex & {$[186,203-207]$} \\
\hline Nitrophorin-7 & Lipocalin & Rhodnius prolixus & AC, V, PAI, AI & $\begin{array}{l}\text { Additionally binds anionic phospholipids to } \\
\text { prevent activation of clotting factors and platelets }\end{array}$ & [208-212] \\
\hline Amine Binding Protein & Lipocalin & Rhodnius prolixus & $\mathrm{V}$ & Binds serotonin and norepinephrine & {$[213,214]$} \\
\hline Triabin & Lipocalin & Triatoma pallidipennis & $\mathrm{AC}$ & Inhibits activation of thrombin & {$[185,215,216]$} \\
\hline Palladipin & Lipocalin & Triatoma pallidipennis & PAI & Collagen-induced PAI, mechanism unknown & {$[181,217,218]$} \\
\hline $\begin{array}{c}\text { Rhodnius Platelet } \\
\text { Aggregation Inhibitor } 1\end{array}$ & Lipocalin & Rhodnius prolixus & PAI & ADP-induced PAI by binding to ADP & {$[219,220]$} \\
\hline Triplatin & Lipocalin & Triatoma infestans & $\mathrm{V}$, anti-NET & Binds thromboxane $\mathrm{A}_{2}$ and prostaglandin $\mathrm{F}_{2 \alpha}$ & [221-223] \\
\hline Triafestin-1, -2 & Lipocalin & Triatoma infestans & $\mathrm{AC}$ & $\begin{array}{l}\text { Inhibits reciprocal activation of Factor XII, } \\
\text { prekallikrein }\end{array}$ & [224] \\
\hline Dipetalodipin & Lipocalin & Dipetalogaster maxima & $\mathrm{V}$, anti-NET & Binds thromboxane $\mathrm{A}_{2}$ and various eicosanoids & {$[180,222]$} \\
\hline Dimiconin & Lipocalin & Triatoma dimidiata & $\mathrm{AC}$ & Inhibits activation of Factor XII & [225] \\
\hline Antigen-5 & Antigen-5 & D. maxima, T. infestans & PAI & Collagen-induced PAI by scavenging free radicals & [226] \\
\hline Apyrase (Triatomine type) & $5^{\prime}$ Nucleotidase & Triatoma infestans & PAI & Degrades ADP & {$[227,228]$} \\
\hline Trialysin & Trialysin & Triatoma infestans & Antimicrobial & Pore formation & [229-231] \\
\hline Protease & Trypsin-like & $\begin{array}{c}\text { T. infestans, } \\
\text { Panstrongylus megistus }\end{array}$ & AC, unknown & Degrades fibrin nets, other unknown function? & {$[232,233]$} \\
\hline Inositol Phosphatase & Inositol phosphatase & Rhodnius prolixus & Unknown & Phosphatidylinositol & [234] \\
\hline Procalin & Lipocalin & Triatoma protracta & Allergen & Unknown & [235] \\
\hline Nitrophorin (Cimex type) & Inositol phosphatase & Cimex lectularius & V, PAI & NO donor & {$[236,237]$} \\
\hline Apyrase (Cimex type) & Apyrase (Cimex type) & Cimex lectularius & PAI & Degrades ADP & {$[183,238]$} \\
\hline
\end{tabular}

${ }^{\text {a }} \mathrm{PAI}=$ platelet aggregation inhibitor; $\mathrm{V}=$ vasodilator; $\mathrm{AC}$ = anticoagulant; $\mathrm{NET}$ = neutrophil extracellular trap; $\mathrm{AI}=$ anti-inflammatory; $\mathrm{PA}=$ platelet aggregation. 
Over the last 25 years, the molecular basis of the venom's action has been studied through two complementary strategies. First, bioactive components have been characterised functionally after purification from crude venom or recombinant expression (Table 2). Secondly, venom protein sequences have been discovered using venom-gland transcriptomics and/or proteomics [239-252]. These studies have revealed much convergent evolution, both between heteropteran lineages with separate evolutionary origins of blood-feeding, and between heteropteran blood-feeders and blood-feeders from other animal taxa. For example, apyrases, enzymes that prevent ADP-induced platelet aggregation by degrading ADP, occur in a wide range of blood-feeding animals including triatomine bugs (Reduviidae: Triatominae) and the bedbug Cimex lectularius (Cimicidae) $[29,253]$. However, while triatomine apyrases belong to the same 5 ' nucleotidase family as mosquito venom apyrases do $[227,254]$, bedbug apyrases belong to an unrelated protein family that has been convergently recruited in the venom of biting sand flies $[238,255]$. Likewise, most venoms used to facilitate blood-feeding have vasodilatory activity, which may be achieved through a variety of mechanisms and targets [175]. In both the bedbug C. lectularius and triatomine bugs of the genus Rhodnius the main vasodilatory components are a group of nitric oxide (NO) donating proteins, the nitrophorins [159,186,256,257]. Perhaps surprisingly, triatomine bugs in the genus Triatoma do not produce nitrophorins and their venom exerts vasodilatory effects through other mechanisms [163]. These observations may support the hypothesis of multiple origins of blood-feeding within Triatominae [162]. Although the triatomine bugs in genus Rhodnius and the bedbug C. lectularius have convergently evolved venom nitrophorins, Rhodnius nitrophorins belong to the lipocalin family whereas $C$. lectularius nitrophorins are descended from an inositol phosphate phosphatase [236]. Many other protein families present have been convergently recruited in venoms from blood-feeding and/or predaceous animals, including the odorant-binding family, cysteine rich secreted protein (CRiSP)/antigen-5 family, and the Kazal domain family [175].

Aside from convergence in function, the evolution of blood-feeding venom reveals radiation and divergence that has allowed closely related proteins to diversify to perform many different functions. For example, lipocalins are proteins that typically have roles in lipid binding, but which have evolved to fulfil an astonishing array of functions in triatomine venom-including donation and sequestration of diverse ligands and inhibition of various host haemostatic proteins (Table 2). Lipocalin-family proteins frequently make up the majority of venom proteins by both number of sequences and abundance [256-258]. Some lipocalin family proteins are multifunctional, such as R. prolixus nitrophorin-2 (prolixin-S), which acts as a NO donor, binds histamine with greater affinity than human receptors, and binds to factor IX/IXa and thereby inhibits activation of coagulation pathways [186,203,205,207].

While highly adapted to blood-feeding, triatomines are nevertheless descended from predaceous reduviids (most likely in the Zelurus group that also includes Stenopodainae and some Reduviinae) $[108,259]$. Some venom components hint at this evolutionary past and may constitute relict activity. For example, trialysin is a $22 \mathrm{kDa}$ pore-forming protein from Triatoma infestans venom that lyses bacterial, protozoan and mammalian cells [229]. However, its occurrence in triatomine venom is of unknown significance since it occurs at concentrations not sufficient to lyse red blood cells, and triatomines in any case store red blood cells in the gut for several weeks before lysis occurs in the posterior midgut. Thus, Amino and colleagues [229] hypothesised that trialysin serves an antiparasitic role by defending the venom glands from microorganisms. Trialysin-like proteins may however contribute to the cytolytic activity that is a hallmark of venoms from predaceous reduviids [6]. Other components are notable due to their absence in triatomine venom. For example, Corzo and colleagues [28] found cystine-rich peptides that are conserved between venoms of the distantly related reduviid subfamilies Peiratinae and Harpactorinae, indicating that the last common ancestor of the Higher Reduviidae—which also includes Triatominae [102,112]—possessed such peptides. However, no evidence of related sequences have to our knowledge been detected in triatomine venom glands, despite deep sequencing (e.g., [248]). The apparent loss of this class of toxins may be 
consistent with its common occurrence in venoms used to facilitate predation, but comparative rarity in blood-feeding venoms [26].

\section{Future Directions}

The venom systems of true bugs are unique, reflecting their unique biology. Further study of their venom will add to our understanding of the evolution of Heteroptera, facilitate efforts to develop heteropterans as efficient biocontrol agents, and contribute to management of the effects of heteropteran envenomations and disease vectoring. The study of neglected animal venoms such as those of heteropterans will also decrease the taxon bias in our current understanding of venoms and venom evolution. In addition, venoms are recognised to be potent sources of bioactive compounds that may be recruited for use as novel bioinsecticides, therapeutic drugs and pharmacological tools [148,260]. The wide range of trophic strategies, prey types and the use of venom defensively suggests that heteropteran venoms may contain a "treasure trove" of molecules with diverse bioactivities. However, little is known about most true bug venoms. This is especially true of predaceous heteropterans, which should form one focus of future work in this area.

The molecular characterisation of venoms from small insects has become increasingly feasible due to advances in technologies such as next-generation sequencing and mass spectrometry. A logical first avenue of approach would be to examine the evolution of protein toxins in Heteroptera by studying venom proteomes from representatives of the major and more common neglected predaceous groups, especially Belostomatidae, Nepidae, Notonectidae, Reduviidae, Anthocoridae, Asopinae, predaceous members of the Miridae, Lygaeidae and Pyrrhocoridae, and predaceous and blood-feeding forms of the Rhypochromidae. Studies combining transcriptomics of venom glands with proteomics of secreted venom are to be favoured, as these provide unambiguous and detailed information on protein toxins that is unbiased by reliance on homology to known protein toxins. In addition, studies of this type may allow subsequent production of toxins by recombinant expression [261] or peptide synthesis [262] in quantities large enough for functional characterisation. Many heteropterans can be induced to expel venom by electrical stimulation [151,263] or the application of muscarinic acetylcholine receptor agonists such as pilocarpine [38,39]. Where venom cannot be extracted by these methods, proteomics of salivary gland homogenates (e.g., [245]) may be an alternative approach to study venom composition.

A complementary approach to transcriptomic/proteomic studies will be functional studies elucidating the physiological actions, active components and molecular targets of predaceous heteropteran venoms. Toxicity studies of crude and fractionated venoms have the potential to tell us which toxin classes-including small non-protein molecules, linear and disulfide-rich peptides, and larger proteins - are most important for prey paralysis, death and liquefaction. To understand their natural function, it is also desirable to screen heteropteran venoms for bioactivity against as many molecular targets as practicable. Targets present within their natural prey should be prioritised, especially those targeted by other venomous animals and known to induce paralysis, such as voltage-gated sodium, calcium and potassium channels, and acetylcholine and glutamate receptors [264]. For those species that inject venom defensively (possibly encompassing most predaceous heteropterans), it will also be of interest to screen venoms for agonists of nociceptive channels capable of inducing pain and aversion that exist in their natural predators, such as transient receptor potential (TRP) channels [265,266] and acid-sensing ion channels (ASICs) [267].

In further characterising the mechanisms and targets of heteropteran venoms, the use of fractionated venoms is desirable, as components with generalised toxicity (e.g., pore-forming proteins) may mask specific activity (e.g., inhibition of ion channels) both in vivo and in cell-based assays in vitro. An important consideration in any biodiscovery work is the evolutionary history leading to present-day heteropteran predators. Because some predatory lineages may have independent origins through trophic switching events (e.g., asopine Pentatomidae and isometopine Miridae, both of which are likely derived from plant-feeding ancestors; Section 1.3), a primary guide in considering target species 
selection and the framing of biological questions should be a detailed understanding of heteropteran phylogeny [2].

Aside from "bottom-up" venom discovery work, Heteroptera offers the opportunity to frame "top-down" questions pertaining to evolution of venom systems. For example, the family Reduviidae contains multiple independent origins of prey specialists descended from generalist ancestors (Section 2.2.1). What effect does prey specialisation have on venom composition in terms of number of components, synonymous versus non-synonymous mutations in proteinaceous toxins, and in the prey specificity of the toxins employed? Do predatory lineages separated by trophic switching events differ markedly in their active components, or have the same classes of toxins been recruited multiple times? How does the presence of prey capture specialisations such as raptorial forearms or fossula spongiosa affect the toxicity and composition of venom? Due to its unique evolutionary history, Heteroptera may be an ideal model taxon in which to investigate these questions.

\section{Conclusions}

Heteroptera is a speciose and diverse group of insects. The basic body plan of ancestral plant-feeding hemipterans, featuring piercing and sucking mouthparts, a well-developed and complex secretory apparatus, and a dedicated delivery channel for saliva through the maxillary stylets, constitutes a powerful morphological preadaptation for envenomation.

The switch from a plant-feeding ancestor to a predaceous true bug likely occurred in the last common ancestor of all Heteroptera and the predatory life-style was retained in most lineages, although secondary transitions to phytophagy occurred, especially in the Pentatomomorpha and Cimicomorpha, with subsequent reversals to predation. Today, venomous heteropterans occupy a wide range of habitats including aquatic, sub-aquatic, marine, terrestrial, arboreal, and cosmopolitan. They range from only a few $\mathrm{mm}$ long as adults in the case of minute pirate bugs to behemoths of the insect world such as giant water bugs, which may measure over $10 \mathrm{~cm}$. Most predatory heteropterans are generalist feeders on invertebrates, but prey specialisation has evolved multiple times, often in concert with complex hunting strategies. Larger species, especially from the aquatic groups, feed on vertebrates including fish, frogs, snakes, turtles and birds. In addition to prey capture, most predatory heteropterans use venom defensively as a deterrent against predators. Several heteropteran groups have eschewed predatory lifestyles in favour of stealing blood from vertebrates, a habit to with they are now highly adapted.

Concomitant with these diverse lifestyles, heteropteran venoms have evolved to have drastically different physiological effects. The venoms of predaceous heteropterans induce rapid paralysis and liquefaction. The active components producing these effects include neurotoxic disulfide-rich peptides, biologically active phospholipids, cytolytic agents and enzymes. However, there are few detailed studies on the venom of predaceous heteropterans, and the relative importance of these components and their evolution across the heteropteran phylogeny is unclear. In the case of blood-feeders, many bioactive components have been identified and characterised that target vertebrate haemostatic and sensory systems, especially from Triatominae. We anticipate that further studies on heteropteran venoms will yield bioactive molecules with a range of biological activities proportionate to the wide range of trophic strategies used by these insects. Thus, heteropteran venoms may represent a treasure-trove of molecules with utility in biotechnology, medicine, and as pharmacological tools.

Acknowledgments: We are grateful to Max Rosenthal for assistance with creating figures, and to Shin-ya Ohba and Margy Green for generously donating photographs. We acknowledge financial support from the Australian Research Council (Discovery Grant DP130103813 to Glenn F. King), the Australian National Health \& Medical Research Council (Principal Research Fellowship to Glenn F. King) and the National Science Foundation (DEB grant 0933853 to Christiane Weirauch).

Author Contributions: Andrew A. Walker, Christiane Weirauch, Bryan G. Fry, and Glenn F. King conceived the review and wrote the manuscript.

Conflicts of Interest: The authors declare no conflict of interest. 


\section{References}

1. Henry, T.J. Biodiversity of Heteroptera. In Insect Biodiversity: Science and Society; Foottit, R.G., Adler, P.H., Eds.; Blackwell Publishing: Oxford, UK, 2009; pp. 223-264.

2. Weirauch, C.; Schuh, R.T. Systematics and evolution of Heteroptera: 25 years of progress. Ann. Rev. Entomol. 2011, 56, 487-510. [CrossRef] [PubMed]

3. World Health Organisation. Investing to Overcome the Global Impact of Neglected Tropical Diseases; World Health Organisation: Geneva, Switzerland, 2015.

4. Walter, J.; Fletcher, E.; Moussaoui, R.; Gandhi, K.; Weirauch, C. Do bites of kissing bugs cause unexplained allergies? Results from a survey in triatomine-exposed and unexposed areas in southern California. PLoS ONE 2012, 7, e44016.

5. Caras, R.A. Dangerous to Man; Barrie \& Jenkins: London, UK, 1976.

6. Edwards, J.S. The action and compostion of the saliva of an assassin bug Platymeris rhadamanthus Gaerst. (Hemiptera, Reduviidae). J. Exp. Biol. 1961, 38, 61-77.

7. Haddad, V.; Schwartz, E.F.; Schwartz, C.A.; Carvalho, L.N. Bites caused by giant water bugs belonging to Belostomatidae family (Hemiptera, Heteroptera) in humans: A report of seven cases. Wilderness Environ. Med. 2010, 21, 130-133. [CrossRef] [PubMed]

8. Readio, P.A. Studies on the biology of the Reduviidae of America North of Mexico. Kans. Univ. Sci. Bull. 1927, 17, 5-249.

9. Zerachia, T.; Bergmann, F.; Shulov, A. Pharmacological activities of the venom of the predaceous bug Holotrichius innesi H. (Heteroptera, Reduviidae). In Animal and Plant Toxins; Kaiser, E., Ed.; Goldman: Munich, Germany, 1973; Volume 143-146.

10. Schaefer, C.W.; Panizzi, A.R. Heteroptera of Economic Importance; CRC Press: Boca Raton, FL, USA, 2000.

11. Fry, B.G.; Roelants, K.; Champagne, D.E.; Scheib, H.; Tyndall, J.D.; King, G.F.; Nevalainen, T.J.; Norman, J.A.; Lewis, R.J.; Norton, R.S.; et al. The toxicogenomic multiverse: Convergent recruitment of proteins into animal venoms. Annu. Rev. Genom. Hum. Genet. 2009, 10, 483-511. [CrossRef] [PubMed]

12. Baptist, B.A. The morphology and physiology of the salivary glands of Hemiptera-Heteroptera. Q. J. Microsc. Sci. 1941, S2-S83, 91-139.

13. Azevedo, D.O.; Zanuncio, J.C.; Zanuncio, J.S.J.; Martins, G.F.; Marques-Silva, S.; Sossai, M.F.; Serrão, J.E. Biochemical and morphological aspects of salivary glands of the predator Brontocoris tabidus (Heteroptera: Pentatomidae). Braz. Arch. Biol. Technol. 2007, 50, 469-477. [CrossRef]

14. Escoubas, P.; Diochot, S.; Corzo, G. Structure and pharmacology of spider venom neurotoxins. Biochimie 2000, 82, 893-907. [CrossRef]

15. Fry, B.G. Venomous Reptiles and Their Toxins: Evolution, Pathophysiology and Biodiscovery; Oxford University Press: Oxford, UK, 2015.

16. Lewis, R.J.; Dutertre, S.; Vetter, I.; Christie, M.J. Conus venom peptide pharmacology. Pharmacol. Rev. 2012, 64, 259-298. [CrossRef] [PubMed]

17. Undheim, E.A.B.; Fry, B.G.; King, G.F. Centipede venom: Recent discoveries and current state of knowledge. Toxins 2015, 7, 679-704. [CrossRef] [PubMed]

18. Zhijian, C.; Feng, L.; Yingliang, W.; Xin, M.; Wenxin, L. Genetic mechanisms of scorpion venom peptide diversification. Toxicon 2006, 47, 348-355. [CrossRef] [PubMed]

19. Jouiaei, M.; Yanagihara, A.A.; Madio, B.; Nevalainen, T.J.; Alewood, P.F.; Fry, B.G. Ancient venom systems: A review on cnidaria toxins. Toxins 2015, 7, 2251-2271. [CrossRef] [PubMed]

20. Cohen, A.C. Solid-to-liquid feeding: The inside(s) out story of extra-oral digestion in predaceous arthropods. Am. Entomol. 1998, 44, 103-116. [CrossRef]

21. Cohen, A.C. Extra-oral digestion in predaceous terrestrial arthropoda. Annu. Rev. Entomol. 1995, 40, 85-103. [CrossRef]

22. Schmidt, J.O. Biochemistry of insect venoms. Annu. Rev. Entomol. 1982, 27, 339-368. [CrossRef] [PubMed]

23. Zlotkin, E. Toxins derived from arthropod venoms specifically affecting insects. In Comprehensive Insect Physiology, Biochemistry and Pharmacology; Kerkut, G.A., Gilbert, L.I., Eds.; Pergamon: Oxford, UK, 1984; Volume 10, pp. 499-546.

24. Picado, C.T. Estudo experimental sobre o veneno de Lethocerus delpontei (de Carlo) (Hemiptero. Belostomatidae). Mem. Inst. Butantan 1936, 10, 303-311. 
25. Zhu, S.; Darbon, H.; Dyason, K.; Verdonck, F.; Tytgat, J. Evolutionary origin of inhibitor cystine knot peptides. FASEB J. 2003, 17, 1765-1767. [CrossRef] [PubMed]

26. Undheim, E.A.; Mobli, M.; King, G.F. Toxin structures as evolutionary tools: Using conserved 3D folds to study the evolution of rapidly evolving peptides. Submitted to Bioessays, February 2016.

27. Bernard, C.; Corzo, G.; Mosbah, A.; Nakajima, T.; Darbon, H. Solution structure of Ptu1, a toxin from the assassin bug Peirates turpis that blocks the voltage-sensitive calcium channel N-type. Biochemistry 2001, 40, 12795-12800. [CrossRef] [PubMed]

28. Corzo, G.; Adachi-Akahane, S.; Nagao, T.; Kusui, Y.; Nakajima, T. Novel peptides from assassin bugs (Hemiptera: Reduviidae): Isolation, chemical and biological characterization. FEBS Lett. 2001, 499, 256-261. [CrossRef]

29. Ribeiro, J.M.C.; Assumpção, T.C.; Francischetti, I.M.B. An insight into the sialomes of bloodsucking Heteroptera. Psyche (Stuttg.) 2012, 2012, 1-16. [CrossRef]

30. Cobben, R.H. Evolutionary trends in Heteroptera, part II: Mouthpart structures and feeding strategies. Meded Landbouwhogesch. Wagening. 1978, 78, 1-407.

31. Cohen, A.C. Feeding adaptations in some predaceous Hemiptera. Ann. Entomol. Soc. Am. 1990, 83, 1215-1223. [CrossRef]

32. Smith, J.J.B. Feeding mechanisms. In Comprehensive Insect Physiology, Biochemistry and Pharmacology; Kerkut, G.A., Gilbert, L.I., Eds.; Pergamon Press: Oxford, UK, 1985; Volume 4, pp. 34-85.

33. Sahayaraj, K.; Kanna, A.V.; Kumar, S.M. Gross morphology of feeding canal, salivary apparatus and digestive enzymes of salivary gland of Catamirus brevipennis (Servile) (Hemiptera: Reduviidae). J. Entomol. Res. Soc. 2010, 12, 37-50.

34. Swart, C.C.; Felgenhauer, B.E. Structure and function of the mouthparts and salivary gland complex of the giant waterbug, Belostoma lutarium (Stål) (Hemiptera: Belostomatidae). Ann. Entomol. Soc. Am. 2003, 95, 870-882. [CrossRef]

35. Haridass, E.T.; Ananthakrishnan, T.N. Functional morphology of the salivary system in some Reduviidae (Insecta-Heteroptera). Proc. Indian Acad. Sci. 1981, 90, 145-160. [CrossRef]

36. Louis, D.; Kumar, R. Morphology of the alimentary and reproductive organs in Reduviidae (Hemiptera: Heteroptera) with comments on interrelationships within the family. Ann. Entomol. Soc. Am. 1973, 66, 635-639. [CrossRef]

37. Barth, R. Estudos anatômicos e histológicos sôbre a subfamília Triatominae (Heteroptera, Reduviidae): IV. parte: O complexo das glândulas salivares de Triatoma infestans. Mem. Inst. Oswaldo Cruz 1954, 52, 517-583. [CrossRef]

38. Miles, P.W.; Slowiak, D. The accessory salivary gland as the source of water in the saliva of Hemiptera: Heteroptera. Experientia 1976, 32, 1011-1012. [CrossRef] [PubMed]

39. Swart, C.C.; Deaton, L.E.; Felgenhauer, B.E. The salivary gland and salivary enzymes of the giant waterbugs (Heteroptera; Belostomatidae). Comp. Biochem. Physiol. A Mol. Integr. Physiol. 2006, 145, 114-122. [CrossRef] [PubMed]

40. Yadav, P.R. Histological evidence on the secretory activity of the accessory salivary gland of Lethocerus indicus Lep. \& Serv. (Heteroptera-Belostomatidae). Proc. Natl. Acad. Sci. India Sect. B 1992, 62B, $284-287$.

41. Miles, P.W.; Sloviak, D. Transport of whole protein molecules from blood to saliva of a plant-bug. Experientia 1970, 26, 611-612. [CrossRef] [PubMed]

42. Miles, P.W. The saliva of Hemiptera. In Advances in Insect Physiology; Treherne, J.E., Berridge, M.J., Wigglesworth, V.B., Eds.; Academic Press: Cambridge, UK, 1972; Volume 9, pp. 183-255.

43. Friend, W.G.; Smith, J.J.B. Feeding in Rhodnius prolixus: Mouthpart activity and salivation, and their correlation with changes of electrical resistance. J. Insect Physiol. 1971, 17, 233-243. [CrossRef]

44. Miles, P.W. Studies on the salivary physiology of plant bugs: Oxidase activity in the salivary apparatus and saliva. J. Insect Physiol. 1964, 10, 121-129. [CrossRef]

45. Miles, P.W. The physiological division of labour in the salivary glands of Oncopeltus fasciatus (Dall.) (Heteroptera: Lygaeidae). Aust. J. Biol. Sci. 1967, 20, 785-798. [PubMed]

46. Maran, S.P.M.; Selvamuthu, K.; Rajan, K.; Kiruba, D.A.; Ambrose, D.P. The salivary protein profile and paralytic potential of three species of Rhynocoris (Hemiptera: Reduviidae) to three insect pests. In Insect Pest Management, a Current Scenario; Ambrose, D.P., Ed.; Entomology Research Unit: Palayamkottai, India, 2011; pp. 346-361. 
47. Morrison, M.N. Gel electrophoretic studies with reference to functional morphology of the salivary glands of Acanthaspis pedestris Stål. (Insecta: Heteroptera : Reduviidae). Proc. Indian Acad. Sci. 1989, 98, 167-173. [CrossRef]

48. Dutertre, S.; Jin, A.H.; Vetter, I.; Hamilton, B.; Sunagar, K.; Lavergne, V.; Dutertre, V.; Fry, B.G.; Antunes, A.; Venter, D.J.; et al. Evolution of separate predation- and defence-evoked venoms in carnivorous cone snails. Nat. Commun. 2014, 5, 3521. [CrossRef] [PubMed]

49. Undheim, E.A.B.; Hamilton, B.R.; Kurniawan, N.D.; Bowlay, G.; Cribb, B.W.; Merritt, D.J.; Fry, B.G.; King, G.F.; Venter, D.J. Production and packaging of a biological arsenal: Evolution of centipede venoms under morphological constraint. Proc. Natl. Acad. Sci. USA 2015, 112, 4026-4031. [CrossRef] [PubMed]

50. Stern, D.L.; Foster, W.A. The evolution of soldiers in aphids. Biol. Rev. 1996, 71, 27-79. [CrossRef] [PubMed]

51. Wang, Y.H.; Cui, Y.; Rédei, D.; Baňař, P.; Xie, Q.; Štys, P.; Damgaard, J.; Chen, P.P.; Yi, W.B.; Wang, Y.; et al. Phylogenetic divergences of the true bugs (Insecta: Hemiptera: Heteroptera), with emphasis on the aquatic lineages: The last piece of the aquatic insect jigsaw originated in the Late Permian/Early Triassic. Cladistics 2015. [CrossRef]

52. Schuh, R.T.; Weirauch, C.; Wheeler, W.C. Phylogenetic relationships within the Cimicomorpha (Hemiptera: Heteroptera): A total-evidence analysis. Syst. Entomol. 2009, 34, 15-48. [CrossRef]

53. Hua, J.; Li, M.; Dong, P.; Cui, Y.; Xie, Q.; Bu, W. Comparative and phylogenomic studies on the mitochondrial genomes of Pentatomomorpha (Insecta: Hemiptera: Heteroptera). BMC Genom. 2008, 9, 1-15. [CrossRef] [PubMed]

54. Li, M.; Tian, Y.; Zhao, Y.; Bu, W. Higher level phylogeny and the first divergence time estimation of Heteroptera (Insecta: Hemiptera) based on multiple genes. PLoS ONE 2012, 7, e32152. [CrossRef] [PubMed]

55. Cobben, R.H. On the original feeding habits of the Hemiptera (Insecta): A reply to Merrill Sweet. Ann. Entomol. Soc. Am. 1979, 72, 711-715. [CrossRef]

56. Schuh, R.T.; Slater, J.A. True Bugs of the World (Hemiptera: Heteroptera): Classification and Natural History; Cornell University Press: New York, NY, USA, 1995.

57. Conticello, S.G.; GIlad, Y.; Avidan, N.; Ben-Asher, E.; Fainzilber, M. Mechanisms for evolving hypervariability: The case of conopeptides. Mol. Biol. Evol. 2001, 18, 120-131. [CrossRef] [PubMed]

58. Olivera, B.M.; Walker, C.; Cartier, G.E.; Hooper, D.; Santos, A.D.; Schoenfeld, R.; Shetty, R.; Watkins, M.; Bandyopadhyay, P.K.; Hillyard, D.R. Speciation of cone snails and interspecific hyperdivergence of their venom peptides. Ann. N. Y. Acad. Sci. 1999, 870, 223-237. [CrossRef] [PubMed]

59. Olivera, B.M.; Watkins, M.; Bandyopadhyay, P.; Imperial, J.S.; de la Cotera, E.P.H.; Aguilar, M.B.; Vera, E.L.; Concepcion, G.P.; Lluisma, A. Adaptive radiation of venomous marine snail lineages and the accelerated evolution of venom peptide genes. Ann. N. Y. Acad. Sci. 2012, 1267, 61-70. [CrossRef] [PubMed]

60. Ohba, S.Y.; Huynh, T.T.T.; Kawada, H.; Le, L.L.; Ngoc, H.T.; Hoang, S.L.; Higa, Y.; Takagi, M. Heteropteran insects as mosquito predators in water jars in southern Vietnam. J. Vector Ecol. 2011, 36, 170-174. [CrossRef] [PubMed]

61. Ohba, S.Y.; Nakasuji, F. Dietary items of predacious aquatic bugs (Nepoidea: Heteroptera) in Japanese wetlands. Limnology 2006, 7, 41-43. [CrossRef]

62. Shaalan, E.A.; Canyon, D.V. Aquatic insect predators and mosquito control. Trop. Biomed. 2009, 26, $223-261$. [PubMed]

63. Zuharah, W.F.; Fadzly, N.; Lester, P.J. Lethal and sublethal impacts of predaceous backswimmer Anisops wakefieldi (Hemiptera: Notonectidae) on the life-history traits of the New Zealand mosquito Culex pervigilans (Diptera: Culicidae). J. Med. Entomol. 2013, 50, 1014-1024. [CrossRef] [PubMed]

64. Hirai, T.; Hidaka, K. Anuran-dependent predation by the giant water bug, Lethocerus deyrollei (Hemiptera: Belostomatidae), in rice fields of Japan. Ecol. Res. 2002, 17, 655-661. [CrossRef]

65. Matheson, R. Bird vs. Insect. Entomol. News 1907, 18, 452.

66. Mori, A.; Ohba, S. Field observations of predation on snakes by the giant water bug. Bull. Herpetol. Soc. Jpn. 2004, 2004, 78-81.

67. Ohba, S.Y. Field observation of predation on a turtle by a giant water bug. Entomol. Sci. 2011, 14, 364-365. [CrossRef]

68. Silva-Cardoso, L.; Caccin, P.; Magnabosco, A.; Patron, M.; Targino, M.; Fuly, A.; Oliveira, G.A.; Pereira, M.H.; do Carmo, M.; Souza, A.S.; et al. Paralytic activity of lysophosphatidylcholine from saliva of the waterbug Belostoma anurum. J. Exp. Biol. 2010, 213, 3305-3310. [CrossRef] [PubMed] 
69. Alves, C.L. Estudo Comparativo da ação da Saliva de Triatomíneos (Heteroptera: Reduviidae) e do Predador Belostoma anurum (Heteroptera: Belostomatidae) Sobre as Preparações de Nervo Isolado de Rattus novergicus e de Vaso Dorsal de Rhodnius prolixus. Master's Thesis, Universidade Federal de Minas Gerais, Belo Horizonte, Brazil, 2007.

70. Dan, A.; Pereira, M.H.; Melo, A.L.; Azeved, A.D.; Freire-Maia, L. Effects induced by the saliva of the aquatic hemipteran Belostoma anurum on the isolated guinea-pig heart. Comp. Biochem. Physiol. 1993, 106, 221-228. [CrossRef]

71. Rees, A.R.; Offord, R.E. Studies on the protease and other enzymes from the venom of Lethocerus cordofanus. Nature 1969, 221, 675-677. [CrossRef] [PubMed]

72. Rastogi, S.C. On the salivary enzymes of some phytophagous and predaceous heteropterans. Sci. Cult. 1962, 28, 479-480.

73. Gutiérrez, J.M.; Lomonte, B. Phospholipases $\mathrm{A}_{2}$ : Unveiling the secrets of a functionally versatile group of snake venom toxins. Toxicon 2013, 62, 27-39. [CrossRef] [PubMed]

74. Šribar, J.; Križaj, I. Secreted phospholipases $A_{2}$-Not just enzymes. Acta Chim. Slov. 2011, 58, 678-688. [PubMed]

75. Tu, A.T.; Hendon, R.R. Characterization of lizard venom hyaluronidase and evidence for its action as a spreading factor. Comp. Biochem. Physiol. B Biochem. Mol. Biol. 1983, 76, 377-383. [CrossRef]

76. Baek, J.H.; Kang, J.S.; Lee, S.H. Differential gene expression profiles in the salivary gland of Ranatra chinensis (Hemiptera: Nepidae). In Proceedings of the Korean Society of Applied Entomology Biannual Meeting, Vivaldi Park, Korea, 12-14 May 2011; p. 284.

77. Caccin, P.; Rigoni, M.; Bisceglie, A.; Rossetto, O.; Montecucco, C. Reversible skeletal neuromuscular paralysis induced by different lysophospholipids. FEBS Lett. 2006, 580, 6317-6321. [CrossRef] [PubMed]

78. Rigoni, M.; Caccin, P.; Gschmeissner, S.; Koster, G.; Postle, A.D.; Rossetto, O.; Schiavo, G.; Montecucco, C. Equivalent effects of snake PLA 2 neurotoxins and lysophospholipid-fatty acid mixtures. Science 2005, 310, 1678-1680. [CrossRef] [PubMed]

79. Locy, W.A. Anatomy and physiology of the family Nepidae. Am. Nat. 1884, 18, 353-367. [CrossRef]

80. Neiswander, C.R. On the anatomy of the head and thorax in Ranatra (Heteroptera). Trans. Am. Entomol. Soc. 1925, 51, 311-320.

81. Grundy, P.; Maelzer, D. Predation by the assassin bug Pristhesancus plagipennis (Walker) (Hemiptera: Reduviidae) of Helicoverpa armigera (Hübner) (Lepidoptera: Noctuidae) and Nezara viridula (L.) (Hemiptera: Pentatomidae) in the laboratory. Aust. J. Entomol. 2000, 39, 280-282. [CrossRef]

82. Smith, R.F.; Hagen, K.S. Enemies of spotted alfalfa aphid. Calif. Agric. 1956, 10, 8-10.

83. De Clercq, P.; Coudron, T.A.; Riddick, E.W. Production of heteropteran predators. In Mass Production of Beneficial Organisms; Morales-Ramos, J., Rojas, G., Shapiro-Ilan, D.I., Eds.; Academic Press: London, UK, 2014.

84. Cohen, A.C. Organization of digestion and preliminary characterization of salivary trypsin-like enzymes in a predaceous heteropteran, Zelus renardii. J. Insect Physiol. 1993, 39, 823-829. [CrossRef]

85. Cohen, A.C. Plant feeding by predatory Heteroptera: Evolutionary and adaptational aspects of trophic switching. In Zoophytophagous Heteroptera: Implication for Life History and Integrated Pest Management; Alomar, O., Ed.; Thomas Say Publications in Entomology: Lanham, MD, USA, 1996; pp. 1-7.

86. Ambrose, D.P.; Maran, S.P.M. Polymorphic diversity in salivary and haemolymph proteins and digestive physiology of assassin bug Rhynocoris marginatus (Fab.) (Het., Reduviidae). J. Appl. Entomol. 2000, 124, 315-317. [CrossRef]

87. Sahayaraj, K.; Sankaralinkam, K.; Balasubramanian, S. Prey influence on the salivary gland and gut enzymes qualitative profile of Rhynocoris marginatus (Fab.) and Catamirus brevipennis (Serville) (Heteroptera: Reduviidae). J. Entomol. 2007, 4, 331-336.

88. Sahayaraj, K.; Subramanium, M.; Rivers, D. Biochemical and electrophoretic analyses of saliva from the predatory reduviid species Rhynocoris marginatus (Fab.). Acta Biochim. Pol. 2013, 60, 91-97.

89. Zeng, F.; Cohen, A.C. Demonstration of amylase from the zoophytophagous anthocorid Orius insidiosus. Arch. Insect Biochem. Physiol. 2000, 44, 136-139. [CrossRef]

90. Boyd, D.W. Digestive enzymes and stylet morphology of Deraeocoris nigritulus (Uhler) (Hemiptera: Miridae) reflect adaptations for predatory habits. Ann. Entomol. Soc. Am. 2003, 96, 667-671. [CrossRef] 
91. Agustí, N.; Cohen, A.C. Lygus hesperus and L. lineolaris (Hemiptera: Miridae), phytophages, zoophages, or omnivores: Evidence of feeding adaptations suggested by the salivary and midgut digestive enzymes. J. Entomol. Sci. 2000, 35, 176-186.

92. Zeng, F.; Cohen, A.C. Comparison of $\alpha$-amylase and protease activities of a zoophytophagous and two phytozoophagous Heteroptera. Comp. Biochem. Physiol. A Mol. Integr. Physiol. 2000, 126, 101-106. [CrossRef]

93. Zeng, F.; Cohen, A.C. Partial characterization of $\alpha$-amylase in the salivary glands of Lygus hesperus and L. lineolaris. Comp. Biochem. Physiol. B Biochem. Mol. Biol. 2000, 126, 9-16. [CrossRef]

94. Zeng, F.; Zhu, Y.C.; Cohen, A.C. Molecular cloning and partial characterization of a trypsin-like protein in salivary glands of Lygus hesperus (Hemiptera: Miridae). Insect Biochem. Mol. Biol. 2002, 32, 455-464. [CrossRef]

95. Colebatch, G.; Cooper, P.; East, P. cDNA cloning of a salivary chymotrypsin-like protease and the identification of six additional cDNAs encoding putative digestive proteases from the green mirid, Creontiades dilutus (Hemiptera: Miridae). Insect Biochem. Mol. Biol. 2002, 32, 1065-1075. [CrossRef]

96. Colebatch, G.; East, P.; Cooper, P. Preliminary characterisation of digestive proteases of the green mirid, Creontiades dilutus (Hemiptera: Miridae). Insect Biochem. Mol. Biol. 2001, 31, 415-423. [CrossRef]

97. Ghamari, M.; Hosseininaveh, V.; Darvishzadeh, A.; Talebi, K. Biochemical characterisation of the tissue degrading enzyme, collagenase, in the spined soldier bug, Podisus maculiventris (Hemiptera: Pentatomidae). J. Plant Prot. Res. 2014, 54, 164-170. [CrossRef]

98. Martínez, L.; do Carmo Queiroz Fialho, M.; Zanuncio, J.; Serrão, J. Ultrastructure and cytochemistry of salivary glands of the predator Podisus nigrispinus (Hemiptera: Pentatomidae). Protoplasma 2014, 251, 535-543. [CrossRef] [PubMed]

99. Oliveira, J.A.; Oliveira, M.G.A.; Guedes, R.N.C.; Soares, M.J. Morphology and preliminary enzyme characterization of the salivary glands from the predatory bug Podisus nigrispinus (Heteroptera: Pentatomidae). Bull. Entomol. Res. 2006, 96, 251-258. [CrossRef] [PubMed]

100. Zibaee, A.; Hoda, H.; Fazeli-Dinan, M. Role of proteases in extra-oral digestion of a predatory bug, Andrallus spinidens. J. Insect Sci. 2012, 12, 51. [CrossRef] [PubMed]

101. Weirauch, C. Hairy attachment structures in Reduviidae (Cimicomorpha, Heteroptera), with observations on the fossula spongiosa in some other Cimicomorpha. Zool. Anz. 2007, 246, 155-175. [CrossRef]

102. Zhang, J.; Gordon, E.R.L.; Forthman, M.; Hwang, W.S.; Walden, K.; Swanson, D.R.; Johnson, K.P.; Meier, R.; Weirauch, C. Evolution of the assassin's arms: Insights from a phylogeny of combined transcriptomic and ribosomal DNA data (Heteroptera: Reduvioidea). Sci. Rep. 2015, Accepted pending revision press.

103. Zhang, G.; Weirauch, C. Sticky predators: A comparative study of sticky glands in harpactorine assassin bugs (Insecta: Hemiptera: Reduviidae). Acta Zool. (Stockh.) 2013, 94, 1-10. [CrossRef]

104. Zhang, G.; Weirauch, C. Molecular phylogeny of Harpactorini (Insecta: Reduviidae): Correlation of novel predation strategy with accelerated evolution of predatory leg morphology. Cladistics 2014, 30, 339-351. [CrossRef]

105. Davis, N.T. Contribution to the morphology and phylogeny of the Reduvioidea. Part IV. The harpactoroid complex. Ann. Entomol. Soc. Am. 1969, 62, 74-94.

106. Zhang, J.; Weirauch, C.; Zhang, G.; Forero, D. Molecular phylogeny of Harpactorinae and Bactrodinae uncovers complex evolution of sticky trap predation in assassin bugs (Heteroptera: Reduviidae). Cladistics 2015. [CrossRef]

107. Weirauch, C.; Forero, D.; Jacobs, D.H. On the evolution of raptorial legs-An insect example (Hemiptera: Reduviidae: Phymatinae). Cladistics 2011, 27, 138-149. [CrossRef]

108. Weirauch, C. Cladistic analysis of Reduviidae (Heteroptera: Cimicomorpha) based on morphological characters. Syst. Entomol. 2008, 33, 229-274. [CrossRef]

109. van der Meijden, A.; Herrel, A.; Summers, A. Comparison of chela size and pincer force in scorpions; getting a first grip. J. Zool. 2010, 280, 319-325. [CrossRef]

110. Livingstone, D.; Ambrose, D.P. Feeding behaviour and predatory efficiency of some reduviids from the Palghat gap, India. J. Madras Univ. Sect. B 1979, 41, 1-25.

111. Maran, S.P.M.; Ambrose, D.P. Paralytic potential of Catamiarus brevipennis (Serville), a potential biological control agent (Insecta: Heteroptera: Reduviidae). In Biotechnological Applications for Integrated Pest Management; Ignacimuth, A., Sen, A., Janarthanan, S., Eds.; Oxford Publishing: New Delhi, India, 2000; pp. 125-131. 
112. Hwang, W.S.; Weirauch, C. Evolutionary history of assassin bugs (Insecta: Hemiptera: Reduviidae): Insights from divergence dating and ancestral state reconstruction. PLOS ONE 2012, 7, e45523. [CrossRef] [PubMed]

113. Kerzhner, I.M. Poluzhestkokrylve Semejstva Nabidae; Nauka: Saint Petersburg, Russia, 1981; Volume 13.

114. Wheeler, A.G. Biology of the Plant Bugs (Hemiptera: Miridae): Pests, Predators, Opportunists; Cornell University Press: Ithaca, NY, USA, 2001.

115. Hickman, V.V. The biology of two emesine bugs (Hemiptera: Reduvudae) occurring on the nests or webs of spiders. J. Entomol. Soc. Aust. (N.S.W.) 1969, 6, 3-18.

116. Wygodzinsky, P.W. A Monograph of the Emesinae (Reduviidae, Hemiptera); Bulletin of the American Museum of Natural History; American Museum of Natural History: New York, NY, USA, 1966; Volume 133.

117. Jackson, R.R.; Wilcox, R.S. Aggressive mimicry, prey-specific predatory behaviour and predator-recognition in the predator-prey interactions of Portia fimbriata and Euryattus sp., jumping spiders from Queensland. Behav. Ecol. Sociobiol. 1990, 26, 111-119. [CrossRef]

118. Soley, F.G.; Taylor, P.W. Ploys and counterploys of assassin bugs and their dangerous spider prey. Behaviour 2013, 150, 397-425. [CrossRef]

119. Wignall, A.E.; Taylor, P.W. Alternative predatory tactics of an araneophagic assassin bug (Stenolemus bituberus). Acta Ethol. 2009, 12, 23-27. [CrossRef]

120. Wignall, A.E.; Taylor, P.W. Predatory behaviour of an araneophagic assassin bug. J. Ethol. 2010, $28,437-445$. [CrossRef]

121. Wignall, A.E.; Taylor, P.W. Assassin bug uses aggressive mimicry to lure spider prey. Proc. Biol. Sci. 2011, 278, 1427-1433. [CrossRef] [PubMed]

122. Jacobson, E. Biological notes on the hemipteran Ptilocerus ochraceus. Tijdschr. Entomol. 1911, 54, $175-179$.

123. McKeown, K.C. Australian Insects. An Introductory Handbook; Royal Zoological Society of New South Wales: Sydney, Australia, 1944.

124. Bulbert, M.W.; Herberstein, M.E.; Cassis, G. Assassin bug requires dangerous ant prey to bite first. Curr. Biol. 2014, 24, R220-R221. [CrossRef] [PubMed]

125. Weirauch, C.; Bulbert, M.; Cassis, G. Comparative trichome morphology in feather-legged assassin bugs (Insecta: Heteroptera: Reduviidae: Holoptilinae). Zool. Anz. 2010, 248, 237-253. [CrossRef]

126. Weirauch, C.; Cassis, G. Attracting ants: The trichome and novel glandular areas on the sternum of Ptilocnemus lemur (Heteroptera: Reduviidae: Holoptilinae). J. N. Y. Entomol. Soc. 2006, 114, 28-37. [CrossRef]

127. Gordon, E.R.L.; Weirauch, C. Efficient capture of natural history data reveals prey conservatism of cryptic termite predators. Mol. Phylogenet. Evol. 2016, 94, 65-73. [CrossRef] [PubMed]

128. McMahan, E.A. Adventures documenting an assassin bug that "fishes" for termites. Am. Entomol. 2005, 51, 202-207. [CrossRef]

129. Forthman, M.; Weirauch, C. Toxic associations: A review of the predatory behaviors of millipede assassin bugs (Hemiptera: Reduviidae: Ectrichodiinae). Eur. J. Entomol. 2012, 109, 147-153. [CrossRef]

130. Haviland, M.D. The Reduviidae of Kartabo, Bartica District, British Guiana. Zoologica 1931, 7, 129-154.

131. Casimir, M. Tegea atropicta Stål (Hemiptera, Reduviidae), an unusual predator of termites. Proc. Linn. Soc. N.S.W. 1960, 85, 230-232.

132. Bérenger, J.M.; Pluot-Sigwalt, D. Notes sur Micrauchenus lineola (Fabricius 1787), espèce termitophile et termitophage (Heteroptera: Reduviidae: Harpactorinae, Apiomerini). Ann. Soc. Entomol. Fr. 2009, 45, 129-133.

133. Haridass, E.T. Feeding and ovipositional behaviour in some reduviids (Insecta-Heteroptera). Proc. Anim. Sci. 1985, 94, 239-247. [CrossRef]

134. Jackson, R.R.; Salm, K.; Nelson, X.J. Specialized prey selection behavior of two East African assassin bugs, Scipinnia [Scipinia] repax and Nagusta sp. that prey on social jumping spiders. J. Insect Sci. 2010, 10, 1-19. [CrossRef] [PubMed]

135. King, G.F.; Hardy, M.G. Spider-venom peptides: Structure, pharmacology, and potential for control of insect pests. Annu. Rev. Entomol. 2013, 58, 475-496. [CrossRef] [PubMed]

136. Barlow, A.; Pook, C.E.; Harrison, R.A.; Wüster, W. Coevolution of diet and prey-specific venom activity supports the role of selection in snake venom evolution. Proc. Biol. Sci. 2009, 276, 2443-2449. [CrossRef] [PubMed]

137. Duda, T.F.; Palumbi, S.R. Gene expression and feeding ecology: Evolution of piscivory in the venomous gastropod genus Conus. Proc. Biol. Sci. 2004, 271, 1165-1174. [CrossRef] [PubMed] 
138. Pekar, S.; Toft, S. Trophic specialisation in a predatory group: The case of prey-specialised spiders (Araneae). Biol. Rev. 2015, 90, 744-761. [CrossRef] [PubMed]

139. Remigio, E.A.; Duda, T.F., Jr. Evolution of ecological specialization and venom of a predatory marine gastropod. Mol. Ecol. 2008, 17, 1156-1162. [CrossRef] [PubMed]

140. Sahayaraj, K.; Muthukumar, S. Zootoxic effects of reduviid Rhynocoris marginatus (Fab.) (Hemiptera: Reduviidae) venomous saliva on Spodoptera litura (Fab.). Toxicon 2011, 58, 415-425. [CrossRef] [PubMed]

141. Hyodo, D.; Himuro, C.; Fujisaki, K. Prey size affects the costs and benefits of group predation in nymphs of the predatory stink bug Andrallus spinidens (Heteroptera: Pentatomidae). J. Ethol. 2014, 32, 173-178. [CrossRef]

142. Slater, J.A.; Carayon, J. Ethiopian Lygaeidae IV: A new predatory lygaeid from Africa with a discussion of its biology and morphology (Hemiptera: Heteroptera). Proc. R. Entomol. Soc. Lond. A 1963, 38, 1-11. [CrossRef]

143. Sahayaraj, K.; Vinothkanna, A. Insecticidal activity of venomous saliva from Rhynocoris fuscipes (Reduviidae) against Spodoptera litura and Helicoverpa armigera by microinjection and oral administration. J. Venom. Anim. Toxins Incl. Trop. Dis. 2011, 17, 486-490. [CrossRef]

144. Edwards, J.S. Spitting as a defensive mechanism in a predatory reduviid. In Proc XI International Congress on Entomology; ICE: Vienna, 1960; Volume 3, pp. 259-263.

145. Fink, L.S. Venom spitting by the green lynx spider, Peucetia viridans (Araneae, Oxyopidae). J. Arachnol. 1984, 12, 372-373.

146. Schmidt, J.O.; Yamane, T.; Matsuura, M.; Starr, C.K. Hornet venoms: Lethalities and lethal capacities. Toxicon 1986, 24, 950-954. [CrossRef]

147. Zerachia, T.; Shulov, A.; Bergmann, F. Hemolysis induced by the venom of the predaceous bug Holotrichius innesi H. (Heteroptera, Reduviidae). In Animal and Plant Toxins; Kaiser, E., Ed.; Goldman: Munich, Germany, 1973; pp. 147-150.

148. King, G.F. Venoms as a platform for human drugs: Translating toxins into therapeutics. Expert Opin. Biol. Ther. 2011, 11, 1469-1484. [CrossRef] [PubMed]

149. Evangelin, G.; Horne, B.; Muthupandi, M.; William, J.S. Venomous saliva of non-haematophagous reduviid bugs (Heteroptera: Reduviidae): A review. Biolife 2014, 2, 615-626.

150. Ambrose, D.P.; Maran, S.P.M. Quantification, protein content and paralytic potential of saliva of fed and prey deprived reduviid Acanthaspis pedestris Stål (Heteroptera: Reduviidae: Reduviinae). Indian J. Environ. Sci. 1999, 3, 11-16.

151. Sahayaraj, K.; Kumar, S.M.; Anandh, G.P. Evaluation of milking and electric shocks for venom collection from hunter reduviids. Entomon 2006, 31, 65-68.

152. Boevé, J.L.; Kuhn-Nentwig, L.; Keller, S.; Nentwig, W. Quantity and quality of venom released by a spider (Cupiennius salei, Ctenidae). Toxicon 1995, 33, 1347-1357. [CrossRef]

153. Johnson, B.D.; Stahnke, H.L.; Koonce, R. A method for estimating Crotalus atrox venom concentrations. Toxicon 1967, 5, 35-38. [CrossRef]

154. Holm, L.; Rosenström, P. Dali server: Conservation mapping in 3D. Nucleic Acids Res. 2010, 38, W545-W549. [CrossRef] [PubMed]

155. Vinoth Kanna, A. Rhynocoris fuscipes Fab. Venomous Saliva Biological Immunomodulatory Activity against Insect Pest and Mice. Ph.D. Thesis, Manonmaniam Sundaranar University, Palayamkottai, India, 2014.

156. Liu, Z.; Dai, J.; Dai, L.; Deng, M.; Hu, Z.; Hu, W.; Liang, S. Function and solution structure of Huwentoxin-X, a specific blocker of N-type calcium channels, from the Chinese bird spider Ornithoctonus huwena. J. Biol. Chem. 2006, 281, 8628-8635. [CrossRef] [PubMed]

157. Martínez, L.C.; Fialho, M.D.C.Q.; Almeida Barbosa, L.C.; Oliveira, L.L.; Zanuncio, J.C.; Serrão, J.E. Stink bug predator kills prey with salivary non-proteinaceous compounds. Insect Biochem. Mol. Biol. 2016, 68, 71-78. [CrossRef] [PubMed]

158. Habibi, J.; Backus, E.A.; Coudron, T.A.; Brandt, S.L. Effect of different host substrates on hemipteran salivary protein profiles. Entomol. Exp. Appl. 2001, 98, 369-375. [CrossRef]

159. Andersen, J.F.; Ding, X.D.; Balfour, C.A.; Shokhireva, T.K.; Champagne, D.E.; Walker, F.A.; Montfort, W.R. Kinetics and equilibria in ligand binding by nitrophorins 1-4: Evidence for stabilization of a nitric oxide-ferriheme complex through a ligand-induced conformational trap. Biochemistry 2000, 39, 10118-10131. [CrossRef] [PubMed] 
160. Fialho, M.C.Q.; Moreira, N.R.; Zanuncio, J.C.; Ribeiro, A.F.; Terra, W.R.; Serrão, J.E. Prey digestion in the midgut of the predatory bug Podisus nigrispinus (Hemiptera: Pentatomidae). J. Insect Physiol. 2012, 58, 850-856. [CrossRef] [PubMed]

161. Baek, J.H.; Lee, S.H. Differential gene expression profiles in the salivary gland of Orius laevigatus. J. Asia-Pac. Entomol. 2014, 17, 729-735. [CrossRef]

162. Schofield, C.J. Biosystematics and evolution of the Triatominae. Cad. Saude Publica 2000, 16, S89-S92. [CrossRef]

163. Ribeiro, J.M.; Schneider, M.; Isaias, T.; Jurberg, J.; Galvão, C.; Guimarães, J.A. Role of salivary antihemostatic components in blood feeding by triatomine bugs (Heteroptera). J. Med. Entomol. 1998, 35, 599-610. [CrossRef] [PubMed]

164. Schofield, C.J.; Galvao, C. Classification, evolution, and species groups within the Triatominae. Acta Trop. 2009, 110, 88-100. [CrossRef] [PubMed]

165. Harrington, B.J. Comments on the blood-feeding tribe Cleradini (Hemiptera: Lygaeidae: Rhyparochrominae) and description of a new genus and new species with the legs modified for grasping. Ann. Entomol. Soc. Am. 1988, 81, 577-581. [CrossRef]

166. Harrington, B.J. Detecting evidence of hematophagy in dry museum specimens of Clerada apicicornis (Hemiptera: Lygaeidae: Rhyparochrominae). Ann. Entomol. Soc. Am. 1990, 83, 545-548. [CrossRef]

167. Lent, H. Sobre o hematofagismo da Clerada apicicornis e outros artropodos; sua importancia na transmissão da doença de Chagas. Mem. Inst. Oswaldo Cruz 1939, 34, 583-606. [CrossRef]

168. Torres, M.; Cárdenas, E.; Pérez, S.; Morales, A. Haematophagy and cleptohaematophagy of Clerada apicicornis (Hemiptera: Lygaeidae), a potential biological control agent of Rhodnius prolixus (Hemiptera: Reduviidae). Mem. Inst. Oswaldo Cruz 2000, 95, 131-133. [CrossRef] [PubMed]

169. Chagas, C. Nova tripanozomiaze humana: Estudos sobre a morfolojia e o ciclo evolutivo do Schizotrypanum cruzi n. gen., n. sp., ajente etiolojico de nova entidade morbida do homem. Mem. Inst. Oswaldo Cruz 1909, 1, 159-218. [CrossRef]

170. Andersen, J.F. Structure and mechanism in salivary proteins from blood-feeding arthropods. Toxicon 2010, 56, 1120-1129. [CrossRef] [PubMed]

171. Andrade, B.B.; Teixeira, C.R.; Barral, A.; Barral-Netto, M. Haematophagous arthropod saliva and host defense system: A tale of tear and blood. An. Acad. Bras. Cienc. 2005, 77, 665-693. [CrossRef] [PubMed]

172. Champagne, D.E. Antihemostatic molecules from saliva of blood-feeding arthropods. Pathophysiol. Haemost. Thromb. 2005, 34, 221-227. [CrossRef] [PubMed]

173. Mans, B.J.; Francischetti, I.M.B. Sialomic perspectives on the evolution of blood-feeding behavior in arthropods: Future therapeutics by natural design. In Toxins and Hemostasis; Kini, R.M., Clemetson, K.J., Markland, F.S., McLane, M.A., Morita, T., Eds.; Springer: Dordrecht, The Netherlands, 2010; pp. 21-44.

174. Ribeiro, J.M.; Francischetti, I.M. Role of arthropod saliva in blood feeding: Sialome and post-sialome perspectives. Annu. Rev. Entomol. 2003, 48, 73-88. [CrossRef] [PubMed]

175. Ribeiro, J.M.C.; Arcà, B. From sialomes to the sialoverse. In Adv. Insect Physiol.; Simpson, S.J., Casas, J., Eds.; Academic Press: Amsterdam, The Netherlands, 2009; Volume 37, pp. 59-118.

176. Alves, C.L.; Araujo, R.N.; Gontijo, N.F.; Pereira, M.H. Importance and physiological effects of hemolymphagy in triatomines (Hemiptera: Reduviidae). J. Med. Entomol. 2011, 48, 372-381. [CrossRef] [PubMed]

177. Herzig, V. Ontogenesis, gender, and molting influence the venom yield in the spider Coremiocnemis tropix (Araneae, Theraphosidae). J. Venom Res. 2010, 1, 76-83. [PubMed]

178. Ribeiro, J.M.; Marinotti, O.; Gonzales, R. A salivary vasodilator in the blood-sucking bug, Rhodnius prolixus. Br. J. Pharmacol. 1990, 101, 932-936. [CrossRef] [PubMed]

179. Ribeiro, J.M.C. The antiserotonin and antihistamine activities of salivary secretion of Rhodnius prolixus. J. Insect Physiol. 1982, 28, 69-75. [CrossRef]

180. Assumpção, T.C.F.; Alvarenga, P.H.; Ribeiro, J.M.C.; Andersen, J.F.; Francischetti, I.M.B. Dipetalodipin, a novel multifunctional salivary lipocalin that inhibits platelet aggregation, vasoconstriction, and angiogenesis through unique binding specificity for $\mathrm{TXA}_{2}, \mathrm{PGF}_{2 \alpha}$, and 15(S)-HETE. J. Biol. Chem. 2010, 285, 39001-39012. [CrossRef] [PubMed]

181. Noeske-Jungblut, C.; Krätzschmar, J.; Haendler, B.; Alagon, A.; Possani, L.; Verhallen, P.; Donner, P.; Schleuning, W.D. An inhibitor of collagen-induced platelet aggregation from the saliva of Triatoma pallidipennis. J. Biol. Chem. 1994, 269, 5050-5053. [PubMed] 
182. Ribeiro, J.M.; Garcia, E.S. Platelet antiaggregating activity in the salivary secretion of the blood sucking bug Rhodnius prolixus. Experientia 1981, 37, 384-386. [CrossRef] [PubMed]

183. Valenzuela, J.G.; Chuffe, O.M.; Ribeiro, J.M.C. Apyrase and anti-platelet activities from the salivary glands of the bed bug Cimex lectularius. Insect Biochem. Mol. Biol. 1996, 26, 557-562. [CrossRef]

184. Hellmann, K.; Hawkins, R.I. Prolixin-S and Prolixin-G; Two anticoagulants from Rhodnius prolixus Stål. Nature 1965, 207, 265-267. [CrossRef] [PubMed]

185. Noeske-Jungblut, C.; Haendler, B.; Donner, P.; Alagon, A.; Possani, L.; Schleuning, W.D. Triabin, a highly potent exosite inhibitor of Thrombin. J. Biol. Chem. 1995, 270, 28629-28634. [CrossRef] [PubMed]

186. Ribeiro, J.M.; Schneider, M.; Guimarães, J.A. Purification and characterization of prolixin-S (nitrophorin 2), the salivary anticoagulant of the blood-sucking bug Rhodnius prolixus. Biochem. J. 1995, 308, 243-249. [CrossRef] [PubMed]

187. Valenzuela, J.G.; Guimaraes, J.A.; Ribeiro, J.M.C. A novel inhibitor of Factor X activation from the salivary glands of the bed bug Cimex lectularius. Exp. Parasitol. 1996, 83, 184-190. [CrossRef] [PubMed]

188. Dan, A.; Pereira, M.H.; Pesquero, J.L.; Diotaiuti, L.; Beirao, P.S. Action of the saliva of Triatoma infestans (Heteroptera: Reduviidae) on sodium channels. J. Med. Entomol. 1999, 36, 875-879. [CrossRef] [PubMed]

189. Habib, A.M.; Wood, J.N.; Cox, J.J. Sodium channels and pain. Handb. Exp. Pharmacol. 2015, 227, 39-56. [PubMed]

190. King, G.F.; Vetter, I. No gain, no pain: $\mathrm{Na}_{V} 1.7$ as an analgesic target. ACS Chem. Neurosci. 2014, 5, 749-751. [CrossRef] [PubMed]

191. Lavoipierre, M.M.; Dickerson, G.; Gordon, R.M. Studies on the methods of feeding of blood-sucking arthropods. I. The manner in which triatomine bugs obtain their blood-meal, as observed in the tissues of the living rodent, with some remarks on the effects of the bite on human volunteers. Ann. Trop. Med. Parasitol. 1959, 53, 235-250. [PubMed]

192. Ribeiro, J.M.C.; Garcia, E.S. The role of the salivary glands in feeding in Rhodnius prolixus. J. Exp. Biol. 1981, 94, 219-230.

193. Champagne, D.E.; Nussenzveig, R.H.; Ribeiro, J.M.C. Purification, partial characterization, and cloning of nitric oxide-carrying heme proteins (nitrophorins) from salivary glands of the blood-sucking insect Rhodnius prolixus. J. Biol. Chem. 1995, 270, 8691-8695. [CrossRef] [PubMed]

194. Ribeiro, J.M.; Hazzard, J.M.; Nussenzveig, R.H.; Champagne, D.E.; Walker, F.A. Reversible binding of nitric oxide by a salivary heme protein from a bloodsucking insect. Science 1993, 260, 539-541. [CrossRef] [PubMed]

195. Golodne, D.M.; Monteiro, R.Q.; Graça-Souza, A.V.; Silva-Neto, M.A.C.; Atella, G.C. Lysophosphatidylcholine acts as an anti-hemostatic molecule in the saliva of the blood-sucking bug Rhodnius prolixus. J. Biol. Chem. 2003, 278, 27766-27771. [CrossRef] [PubMed]

196. Ambrus, A.; Friedrich, K.; Somogyi, Á. Oligomerization of nitrophorins. Anal. Biochem. 2006, 352, $286-295$. [CrossRef] [PubMed]

197. Andersen, J.F.; Champagne, D.E.; Weichsel, A.; Ribeiro, J.M.C.; Balfour, C.A.; Dress, V.; Montfort, W.R. Nitric oxide binding and crystallization of recombinant nitrophorin I, a nitric oxide transport protein from the blood-sucking bug Rhodnius prolixus. Biochemistry 1997, 36, 4423-4428. [CrossRef] [PubMed]

198. Andersen, J.F.; Weichsel, A.; Balfour, C.A.; Champagne, D.E.; Montfort, W.R. The crystal structure of Nitrophorin 4 at $1.5 \AA$ resolution: Transport of nitric oxide by a lipocalin-based heme protein. Structure 1998, 6, 1315-1327. [CrossRef]

199. Berry, R.E.; Muthu, D.; Yang, F.; Walker, F.A. NMR studies of the dynamics of high-spin Nitrophorins: Comparative studies of NP4 and NP2 at close to physiological pH. Biochemistry 2015, 54, 221-239. [CrossRef] [PubMed]

200. He, C.; Nishikawa, K.; Erdem, Ö.F.; Reijerse, E.; Ogata, H.; Lubitz, W.; Knipp, M. Complexes of ferriheme nitrophorin 4 with low-molecular weight thiol(ate)s occurring in blood plasma. J. Inorg. Biochem. 2013, 122, 38-48. [CrossRef] [PubMed]

201. Weichsel, A.; Andersen, J.F.; Champagne, D.E.; Walker, F.A.; Montfort, W.R. Crystal structures of a nitric oxide transport protein from a blood-sucking insect. Nat. Struct. Biol. 1998, 5, 304-309. [CrossRef] [PubMed]

202. Weichsel, A.; Andersen, J.F.; Roberts, S.A.; Montfort, W.R. Nitric oxide binding to Nitrophorin 4 induces complete distal pocket burial. Nat. Struct. Biol. 2000, 7, 551-554. [PubMed]

203. Andersen, J.F.; Montfort, W.R. The crystal structure of Nitrophorin 2: A trifunctional antihemostatic protein from the saliva of Rhodnius prolixus. J. Biol. Chem. 2000, 275, 30496-30503. [CrossRef] [PubMed] 
204. Gudderra, N.P.; Ribeiro, J.M.C.; Andersen, J.F. Structural determinants of Factor IX(a) binding in Nitrophorin 2, a lipocalin inhibitor of the intrinsic coagulation pathway. J. Biol. Chem. 2005, 280, 25022-25028. [CrossRef] [PubMed]

205. Isawa, H.; Yuda, M.; Yoneda, K.; Chinzei, Y. The insect salivary protein, Prolixin-S, inhibits Factor IXa generation and Xase complex formation in the blood coagulation pathway. J. Biol. Chem. 2000, 275, 6636-6641. [CrossRef] [PubMed]

206. Yuda, M.; Higuchi, K.; Sun, J.; Kureishi, Y.; Ito, M.; Chinzei, Y. Expression, reconstitution and characterization of Prolixin-S as a vasodilator. Eur. J. Biochem. 1997, 249, 337-342. [CrossRef] [PubMed]

207. Zhang, Y.; Ribeiro, J.M.C.; Guimarães, J.A.; Walsh, P.N. Nitrophorin-2:A novel mixed-type reversible specific inhibitor of the intrinsic Factor-X activating complex. Biochemistry 1998, 37, 10681-10690. [CrossRef] [PubMed]

208. Andersen, J.F.; Gudderra, N.P.; Francischetti, I.M.B.; Valenzuela, J.G.; Ribeiro, J.M.C. Recognition of anionic phospholipid membranes by an antihemostatic protein from a blood-feeding insect. Biochemistry 2004, 43, 6987-6994. [CrossRef] [PubMed]

209. Knipp, M.; Soares, R.P.; Pereira, M.H. Identification of the native N-terminus of the membrane attaching ferriheme protein nitrophorin 7 from Rhodnius prolixus. Anal. Biochem. 2012, 424, 79-81. [CrossRef] [PubMed]

210. Knipp, M.; Yang, F.; Berry, R.E.; Zhang, H.; Shokhirev, M.N.; Walker, F.A. Spectroscopic and functional characterization of Nitrophorin 7 from the blood-feeding insect Rhodnius prolixus reveals an important role of its isoform-specific N-Terminus for proper protein function. Biochemistry 2007, 46, 13254-13268. [CrossRef] [PubMed]

211. Oliveira, A.; Allegri, A.; Bidon-Chanal, A.; Knipp, M.; Roitberg, A.E.; Abbruzzetti, S.; Viappiani, C.; Luque, F.J. Kinetics and computational studies of ligand migration in nitrophorin 7 and its $\Delta 1-3$ mutant. Biochim. Biophys. Acta 2013, 1834, 1711-1721. [CrossRef] [PubMed]

212. Varghese, S.; Yang, F.; Pacheco, V.; Wrede, K.; Medvedev, A.; Ogata, H.; Knipp, M.; Heise, H. Expression, purification, and solid-state NMR characterization of the membrane binding heme protein Nitrophorin 7 in two electronic spin states. Biochemistry 2013, 52, 7031-7040. [CrossRef] [PubMed]

213. Andersen, J.F.; Francischetti, I.M.B.; Valenzuela, J.G.; Schuck, P.; Ribeiro, J.M.C. Inhibition of hemostasis by a high affinity biogenic amine-binding protein from the saliva of a blood-feeding insect. J. Biol. Chem. 2003, 278, 4611-4617. [CrossRef] [PubMed]

214. Xu, X.; Chang, B.W.; Mans, B.J.; Ribeiro, J.M.; Andersen, J.F. Structure and ligand-binding properties of the biogenic amine-binding protein from the saliva of a blood-feeding insect vector of Trypanosoma cruzi. Acta Crystallogr. D Biol. Crystallogr. 2013, 69, 105-113. [CrossRef] [PubMed]

215. Fuentes-Prior, P.; Noeske-Jungblut, C.; Donner, P.; Schleuning, W.-D.; Huber, R.; Bode, W. Structure of the thrombin complex with triabin, a lipocalin-like exosite-binding inhibitor derived from a triatomine bug. Proc. Natl. Acad. Sci. USA 1997, 94, 11845-11850. [CrossRef] [PubMed]

216. Glusa, E.; Bretschneider, E.; Daum, J.; Noeske-Jungblut, C. Inhibition of thrombin-mediated cellular effects by triabin, a highly potent anion-binding exosite thrombin inhibitor. Thromb. Haemost. 1997, 77, 1196-1200. [PubMed]

217. Haendler, B.; Becker, A.; Noeske-Jungblut, C.; Kratzchmar, J.; Donner, P.; Schleuning, W.D. Expression of active recombinant palidipin, a novel platelet aggregation inhibitor, in the periplasm of Escherichia coli. Biochem. J. 1995, 307. [CrossRef]

218. Haendler, B.; Becker, A.; Noeske-Jungblut, C.; Krãtzschmar, J.; Donner, P.; Schleuning, W.D. Expression, purification and characterisation of recombinant pallidipin, a novel platelet aggregation inhibitor from the haematophageous triatomine bug Triatoma pallidipennis. Blood Coagul. Fibrinolysis 1996, 7, 183-186. [CrossRef] [PubMed]

219. Francischetti, I.M.B.; Andersen, J.F.; Ribeiro, J.M.C. Biochemical and functional characterization of recombinant Rhodnius prolixus Platelet Aggregation Inhibitor 1 as a novel lipocalin with high affinity for adenosine diphosphate and other adenine nucleotides. Biochemistry 2002, 41, 3810-3818. [CrossRef] [PubMed]

220. Francischetti, I.M.B.; Ribeiro, J.M.C.; Champagne, D.; Andersen, J. Purification, cloning, expression, and mechanism of action of a novel platelet aggregation inhibitor from the salivary gland of the blood-sucking bug, Rhodnius prolixus. J. Biol. Chem. 2000, 275, 12639-12650. [CrossRef] [PubMed] 
221. Ma, D.; Assumpção, T.C.F.; Li, Y.; Andersen, J.F.; Ribeiro, J.M.C.; Francischetti, I.M.B. Triplatin, a platelet aggregation inhibitor from the salivary gland of the triatomine vector of Chagas Disease, binds to TXA $\mathrm{A}_{2}$ but does not interact with GPVI. Thromb. Haemost. 2012, 107, 111-123. [CrossRef] [PubMed]

222. Mizurini, D.M.; Aslan, J.S.; Gomes, T.; Ma, D.; Francischetti, I.M.B.; Monteiro, R.Q. Salivary thromboxane $\mathrm{A}_{2}$-binding proteins from triatomine vectors of Chagas disease inhibit platelet-mediated Neutrophil Extracellular Traps (NETs) formation and arterial thrombosis. PLoS Negl. Trop. Dis. 2015, 9, e0003869. [CrossRef] [PubMed]

223. Morita, A.; Isawa, H.; Orito, Y.; Iwanaga, S.; Chinzei, Y.; Yuda, M. Identification and characterization of a collagen-induced platelet aggregation inhibitor, triplatin, from salivary glands of the assassin bug, Triatoma infestans. FEBS J. 2006, 273, 2955-2962. [CrossRef] [PubMed]

224. Isawa, H.; Orito, Y.; Jingushi, N.; Iwanaga, S.; Morita, A.; Chinzei, Y.; Yuda, M. Identification and characterization of plasma kallikrein-kinin system inhibitors from salivary glands of the blood-sucking insect Triatoma infestans. FEBS J. 2007, 274, 4271-4286. [CrossRef] [PubMed]

225. Ishimaru, Y.; Gomez, E.A.; Zhang, F.; Martini-Robles, L.; Iwata, H.; Sakurai, T.; Katakura, K.; Hashiguchi, Y.; Kato, H. Dimiconin, a novel coagulation inhibitor from the kissing bug, Triatoma dimidiata, a vector of Chagas disease. J. Exp. Biol. 2012, 215, 3597-3602. [CrossRef] [PubMed]

226. Assumpção, T.C.F.; Ma, D.; Schwarz, A.; Reiter, K.; Santana, J.M.; Andersen, J.F.; Ribeiro, J.M.C.; Nardone, G.; $\mathrm{Yu}$, L.L.; Francischetti, I.M.B. Salivary antigen-5/CAP family members are $\mathrm{Cu}^{2+}$-dependent antioxidant enzymes that scavenge $\mathrm{O}_{2-}$ and inhibit collagen-induced platelet aggregation and neutrophil oxidative burst. J. Biol. Chem. 2013, 288, 14341-14361. [CrossRef] [PubMed]

227. Faudry, E.; Lozzi, S.P.; Santana, J.M.; D’Souza-Ault, M.; Kieffer, S.; Felix, C.R.; Ricart, C.A.O.; Sousa, M.V.; Vernet, T.; Teixeira, A.R.L. Triatoma infestans apyrases belong to the $5^{\prime}$-nucleotidase family. J. Biol. Chem. 2004, 279, 19607-19613. [CrossRef] [PubMed]

228. Faudry, E.; Santana, J.M.; Ebel, C.; Vernet, T.; Teixeira, A.R.L. Salivary apyrases of Triatoma infestans are assembled into homo-oligomers. Biochem. J. 2006, 396, 509-515. [CrossRef] [PubMed]

229. Amino, R.; Martins, R.M.; Procopio, J.; Hirata, I.Y.; Juliano, M.A.; Schenkman, S. Trialysin, a novel pore-forming protein from saliva of hematophagous insects activated by limited proteolysis. J. Biol. Chem. 2002, 277, 6207-6213. [CrossRef] [PubMed]

230. Martins, R.M.; Amino, R.; Daghastanli, K.R.; Cuccovia, I.M.; Juliano, M.A.; Schenkman, S. A short proregion of trialysin, a pore-forming protein of Triatoma infestans salivary glands, controls activity by folding the N-terminal lytic motif. FEBS J. 2008, 275, 994-1002. [CrossRef] [PubMed]

231. Martins, R.M.; Sforça, M.L.; Amino, R.; Juliano, M.A.; Oyama, S.; Juliano, L.; Pertinhez, T.A.; Spisni, A.; Schenkman, S. Lytic activity and structural differences of amphipathic peptides derived from Trialysin. Biochemistry 2006, 45, 1765-1774. [CrossRef] [PubMed]

232. Amino, R.; Tanaka, A.S.; Schenkman, S. Triapsin, an unusual activatable serine protease from the saliva of the hematophagous vector of Chagas' disease Triatoma infestans (Hemiptera: Reduviidae). Insect Biochem. Mol. Biol. 2001, 31, 465-472. [CrossRef]

233. Meiser, C.K.; Piechura, H.; Meyer, H.E.; Warscheid, B.; Schaub, G.A.; Balczun, C. A salivary serine protease of the haematophagous reduviid Panstrongylus megistus: Sequence characterization, expression pattern and characterization of proteolytic activity. Insect Mol. Biol. 2010, 19, 409-421. [CrossRef] [PubMed]

234. Andersen, J.F.; Ribeiro, J.M.C. A secreted salivary inositol polyphosphate 5-phosphatase from a blood-feeding insect: Allosteric activation by soluble phosphoinositides and phosphatidylserine. Biochemistry 2006, 45, 5450-5457. [CrossRef] [PubMed]

235. Paddock, C.D.; McKerrow, J.H.; Hansell, E.; Foreman, K.W.; Hsieh, I.; Marshall, N. Identification, cloning, and recombinant expression of Procalin, a major triatomine allergen. J. Immunol. 2001, 167, 2694-2699. [CrossRef] [PubMed]

236. Valenzuela, J.G.; Ribeiro, J.M.C. Purification and cloning of the salivary nitrophorin from the hemipteran Cimex lectularius. J. Exp. Biol. 1998, 201, 2659-2664. [PubMed]

237. Valenzuela, J.G.; Walker, F.A.; Ribeiro, J.M. A salivary nitrophorin (nitric-oxide-carrying hemoprotein) in the bedbug Cimex lectularius. J. Exp. Biol. 1995, 198, 1519-1526. [PubMed]

238. Valenzuela, J.G.; Charlab, R.; Galperin, M.Y.; Ribeiro, J.M.C. Purification, cloning, and expression of an apyrase from the bed bug Cimex lectularius : A new type of nucleotide-binding enzyme. J. Biol. Chem. 1998, 273, 30583-30590. [CrossRef] [PubMed] 
239. Assumpção, T.C.F.; Francischetti, I.M.; Andersen, J.F.; Schwarz, A.; Santana, J.M.; Ribeiro, J.M. An insight into the sialome of the blood-sucking bug Triatoma infestans, a vector of Chagas' disease. Insect Biochem. Mol. Biol. 2008, 38, 213-232. [CrossRef] [PubMed]

240. Assumpção, T.C.F.; Charneau, S.; Santiago, P.B.M.; Francischetti, I.M.B.; Meng, Z.; Araújo, C.N.; Pham, V.M.; Queiroz, R.M.L.; de Castro, C.N.; Ricart, C.A.; et al. Insight into the salivary transcriptome and proteome of Dipetalogaster maxima. J. Proteome Res. 2011, 10, 669-679. [CrossRef] [PubMed]

241. Assumpção, T.C.F.; Eaton, D.P.; Pham, V.M.; Francischetti, I.M.; Aoki, V.; Hans-Filho, G.; Rivitti, E.A.; Valenzuela, J.G.; Diaz, L.A.; Ribeiro, J.M. An insight into the sialotranscriptome of Triatoma matogrossensis, a kissing bug associated with fogo selvagem in South America. Am. J. Trop. Med. Hyg. 2012, 86, 1005-1014. [CrossRef] [PubMed]

242. Bussacos, A.C.; Nakayasu, E.S.; Hecht, M.M.; Assumpção, T.C.; Parente, J.A.; Soares, C.M.; Santana, J.M.; Almeida, I.C.; Teixeira, A.R. Redundancy of proteins in the salivary glands of Panstrongylus megistus secures prolonged procurement for blood meals. J. Proteomics 2011, 74, 1693-1700. [CrossRef] [PubMed]

243. Bussacos, A.C.; Nakayasu, E.S.; Hecht, M.M.; Parente, J.A.; Soares, C.M.; Teixeira, A.R.; Almeida, I.C. Diversity of anti-haemostatic proteins in the salivary glands of Rhodnius species transmitters of Chagas disease in the greater Amazon. J. Proteomics 2011, 74, 1664-1672. [CrossRef] [PubMed]

244. Costa, C.M.; Sousa, M.V.; Ricart, C.A.; Santana, J.M.; Teixeira, A.R.; Roepstorff, P.; Charneau, S. 2-DE-based proteomic investigation of the saliva of the Amazonian triatomine vectors of Chagas disease: Rhodnius brethesi and Rhodnius robustus. J. Proteomics 2011, 74, 1652-1663. [CrossRef] [PubMed]

245. Francischetti, I.M.; Calvo, E.; Andersen, J.F.; Pham, V.M.; Favreau, A.J.; Barbian, K.D.; Romero, A.; Valenzuela, J.G.; Ribeiro, J.M. Insight into the sialome of the bed bug, Cimex lectularius. J. Proteome Res. 2010, 9, 3820-3831. [CrossRef] [PubMed]

246. Kato, H.; Jochim, R.C.; Gomez, E.A.; Sakoda, R.; Iwata, H.; Valenzuela, J.G.; Hashiguchi, Y. A repertoire of the dominant transcripts from the salivary glands of the blood-sucking bug, Triatoma dimidiata, a vector of Chagas disease. Infect. Genet. Evol. 2010, 10, 184-191. [CrossRef] [PubMed]

247. Ribeiro, J.M.; Assumpção, T.C.; Pham, V.M.; Francischetti, I.M.; Reisenman, C.E. An insight into the sialotranscriptome of Triatoma rubida (Hemiptera: Heteroptera). J. Med. Entomol. 2012, 49, 563-572. [CrossRef] [PubMed]

248. Ribeiro, J.M.; Schwarz, A.; Francischetti, I.M. A deep insight into the sialotranscriptome of the Chagas disease vector, Panstrongylus megistus (Hemiptera: Heteroptera). J. Med. Entomol. 2015, 52, 351-358. [CrossRef] [PubMed]

249. Ribeiro, J.M.C.; Andersen, J.; Silva-Neto, M.A.C.; Pham, V.M.; Garfield, M.K.; Valenzuela, J.G. Exploring the sialome of the blood-sucking bug Rhodnius prolixus. Insect Biochem. Mol. Biol. 2004, 34, 61-79. [CrossRef] [PubMed]

250. Santos, A.; Ribeiro, J.M.; Lehane, M.J.; Gontijo, N.F.; Veloso, A.B.; Sant'Anna, M.R.; Nascimento Araujo, R.; Grisard, E.C.; Pereira, M.H. The sialotranscriptome of the blood-sucking bug Triatoma brasiliensis (Hemiptera, Triatominae). Insect Biochem. Mol. Biol. 2007, 37, 702-712. [CrossRef] [PubMed]

251. Schwarz, A.; Helling, S.; Collin, N.; Teixeira, C.R.; Medrano-Mercado, N.; Hume, J.C.C.; Assumpção, T.C.; Marcus, K.; Stephan, C.; Meyer, H.E.; et al. Immunogenic salivary proteins of Triatoma infestans: Development of a recombinant antigen for the detection of low-level Infestation of Triatomines. PLoS Negl. Trop. Dis. 2009, 3, e532. [CrossRef] [PubMed]

252. Sant'Anna, M.R.V.; Araújo, J.G.V.C.; Pereira, M.H.; Pesquero, J.L.; Diotaiuti, L.; Lehane, S.M.; Lehane, M.J. Molecular cloning and sequencing of salivary gland-specific cDNAs of the blood-sucking bug Triatoma brasiliensis (Hemiptera: Reduviidae). Insect Mol. Biol. 2002, 11, 585-593. [CrossRef] [PubMed]

253. Hughes, A.L. Evolution of the salivary apyrases of blood-feeding arthropods. Gene 2013, 527, $123-130$. [CrossRef] [PubMed]

254. Champagne, D.E.; Smartt, C.T.; Ribeiro, J.M.; James, A.A. The salivary gland-specific apyrase of the mosquito Aedes aegypti is a member of the 5'-nucleotidase family. Proc. Natl. Acad. Sci. USA 1995, 92, 694-698. [CrossRef] [PubMed]

255. Valenzuela, J.G.; Belkaid, Y.; Rowton, E.; Ribeiro, J.M. The salivary apyrase of the blood-sucking sand fly Phlebotomus papatasi belongs to the novel Cimex family of apyrases. J. Exp. Biol. 2001, 204, 229-237. [PubMed]

256. Ascenzi, P.; Nardini, M.; Bolognesi, M.; Montfort, W.R. Nitrophorins: Lipocalin-based heme proteins transporting nitric oxide. Biochem. Mol. Biol. Educ. 2002, 30, 68-71. [CrossRef] 
257. Montfort, W.R.; Weichsel, A.; Andersen, J.F. Nitrophorins and related antihemostatic lipocalins from Rhodnius prolixus and other blood-sucking arthropods. Biochim. Biophys. Acta 2000, 1482, 110-118. [CrossRef]

258. Andersen, J.F.; Gudderra, N.P.; Francischetti, I.M.B.; Ribeiro, J.M.C. The role of salivary lipocalins in blood feeding by Rhodnius prolixus. Arch. Insect Biochem. Physiol. 2005, 58, 97-105. [CrossRef] [PubMed]

259. Weirauch, C.; Munro, J.B. Molecular phylogeny of the assassin bugs (Hemiptera: Reduviidae), based on mitochondrial and nuclear ribosomal genes. Mol. Phylogenet. Evol. 2009, 53, 287-299. [CrossRef] [PubMed]

260. Windley, M.J.; Herzig, V.; Dziemborowicz, S.A.; Hardy, M.C.; King, G.F.; Nicholson, G.M. Spider-venom peptides as bioinsecticides. Toxins 2012, 4, 191-227. [CrossRef] [PubMed]

261. Klint, J.K.; Senff, S.; Saez, N.J.; Seshadri, R.; Lau, H.Y.; Bende, N.S.; Undheim, E.A.; Rash, L.D.; Mobli, M.; King, G.F. Production of recombinant disulfide-rich venom peptides for structural and functional analysis via expression in the periplasm of E. coli. PLOS ONE 2013, 8, e63865.

262. Schroeder, C.I.; Rash, L.D.; Vila-Farrés, X.; Rosengren, K.J.; Mobli, M.; King, G.F.; Alewood, P.F.; Craik, D.J.; Durek, T. Chemical synthesis, 3D structure, and ASIC binding site of the toxin Mambalgin-2. Angew. Chem. 2014, 53, 1017-1020. [CrossRef] [PubMed]

263. Pineda, S.S.; Melgar, S.; Dorn, P.L.; Agreda, E.; Rodas, A.; Monroy, C. Salivary protein profiles distinguish triatomine species and populations of Triatoma dimidiata (Hemiptera: Reduviidae). J. Med. Entomol. 2008, 45, 52-58. [CrossRef]

264. Schwartz, E.F.; Mourão, C.B.F.; Moreira, K.G.; Camargos, T.S.; Mortari, M.R. Arthropod venoms: A vast arsenal of insecticidal neuropeptides. Biopolymers 2012, 98, 385-405. [CrossRef] [PubMed]

265. Cuypers, E.; Yanagihara, A.; Karlsson, E.; Tytgat, J. Jellyfish and other cnidarian envenomations cause pain by affecting TRPV1 channels. FEBS Lett. 2006, 580, 5728-5732. [CrossRef] [PubMed]

266. Siemens, J.; Zhou, S.; Piskorowski, R.; Nikai, T.; Lumpkin, E.A.; Basbaum, A.I.; King, D.; Julius, D. Spider toxins activate the capsaicin receptor to produce inflammatory pain. Nature 2006, 444, 208-212. [CrossRef] [PubMed]

267. Bohlen, C.J.; Chesler, A.T.; Sharif-Naeini, R.; Medzihradszky, K.F.; Zhou, S.; King, D.; Sanchez, E.E.; Burlingame, A.L.; Basbaum, A.I.; Julius, D. A heteromeric Texas coral snake toxin targets acid-sensing ion channels to produce pain. Nature 2011, 479, 410-414. [CrossRef] [PubMed]

(C) 2016 by the authors; licensee MDPI, Basel, Switzerland. This article is an open access article distributed under the terms and conditions of the Creative Commons by Attribution (CC-BY) license (http://creativecommons.org/licenses/by/4.0/). 